\title{
Dohnányi's Orchestrations of Schubert's Fantasy in F Minor and the Moments musicaux Piano Cycle
}

\author{
Anna LASKAI*
}

Institute for Musicology, Research Centre for the Humanities, Táncsics Mihály u. 7., H-1014, Budapest, Hungary

\section{ORIGINAL RESEARCH PAPER}

Received: June 2, 2020 • Accepted: December 8, 2020

(c) 2020 The Author(s)

\begin{abstract}
Ernst von Dohnányi's brilliant instrumentation skills were already recognized by his contemporaries. His former disciple and first monographer Bálint Vázsonyi published an anecdote, according to which Béla Bartók considered the orchestral version of Ruralia hungarica (op. 32) as the first truly "orchestrated" Hungarian symphonic work. Nevertheless, neither Dohnányi's own orchestration practices nor the transcriptions he prepared for symphony orchestra from the works of other composers have been studied. This paper examines two of these orchestrations, made in 1928 on the occasion of the Schubert Centenary - Dohnányi's orchestral transcriptions of the Fantasy in F Minor, originally written for piano four hands, and the piano cycle Moments musicaux - both being virtually unknown to the public. The analysis also provides an insight into Dohnányi's interpretation of Schubert, including his approach to the Austrian composer.
\end{abstract}

\section{KEYWORDS}

Ernst von Dohnányi, Franz Schubert, orchestration, Fantasy in F Minor for piano duet (D. 940), Moments musicaux (D. 780$)$

\footnotetext{
*Corresponding author. E-mail: Laskai.Anna@abtk.hu
} 
Ernst von Dohnányi's proverbially brilliant orchestration skills were already recognized by his contemporaries. His first monographer Bálint Vázsonyi published an anecdote, typical of these opinions, according to which Béla Bartók regarded the orchestral version of Ruralia hungarica (op. 32 ) as the first truly "orchestrated" Hungarian symphonic work. ${ }^{1}$ Nevertheless, neither Dohnányi’s own orchestration practices nor the symphonic arrangements he made from the works of other composers have been comprehensively investigated. The present study examines two orchestrations Dohnányi made in 1928, on the occasion of the Schubert Centenary. Both being virtually unknown to today's public, these are the orchestral transcriptions of Franz Schubert's Fantasy in F Minor for piano duet and the piano cycle Moments musicaux. Dohnányi had previously made arrangements for piano; however, these were the first compositions he orchestrated. His interest in orchestral sound may also have played a role in his decision to prepare both orchestrations: at that time, he had already been conductor of the Budapest Philharmonic Society for almost a decade.

In the first part of my study, I shall outline the context, in which both orchestrations were premiered, i.e. the Budapest events of the 1928 Schubert Centenary. This presentation will also touch upon the question of how Dohnányi's instrumentations were received as well as Dohnányi's reception of Schubert as pianist and conductor. The presence of Schubert's symphonic works in the Hungarian capital will be reviewed from a broader perspective in the second part of my study where, in addition to the Budapest Philharmonic Orchestra led by Dohnányi, I will address the repertoire of other Budapest orchestras. In the third part, I will deal with further nineteenth- and twentiethcentury composers who made orchestrations of the Fantasy in F Minor and the piano cycle Moments musicaux in addition to Dohnányi. Finally, in the fourth part of my article, I will examine the most important features of both of Dohnányi's orchestrations with the aid of musical examples.

\section{THE SCHUBERT CENTENARY IN BUDAPEST}

The centenary of Schubert's death was celebrated in the concert life of the Hungarian capital between November 19 and 26, 1928 with a series of music festivals, dedicated to and named after the composer. The organizing committee of the celebrations included both eminent musicians and prominent public figures: its honorary president was Ödön Mihalovich, a former director of the Budapest Music Academy, while the chairman's position was occupied by Count Albert Apponyi. The committee organized a total of five festive events, ${ }^{2}$ ranging from symphonic and chamber music concerts to piano recitals. ${ }^{3}$ The biggest event was the Festival's opening concert, organized at the Opera House on November 19, 1928, with the performance, conducted by Nándor Rékai, of Schubert's "Unfinished" Symphony, his one-act Singspiel Die Verschworenen, and Dohnányi's orchestration of the piano cycle Moments musicaux. The latter was staged as a

\footnotetext{
${ }^{1}$ Bálint VÁZSONYI, Dohnányi Ernö (Budapest: Nap Kiadó, 2002), 343. The anecdote in question was reiterated by József Ujfalussy in a documentary on Dohnányi. Ujfalussy himself heard the story from his former composition teacher Emil Szabó (1898-1970), a former disciple of Bartók's. The 1993 documentary, entitled Dohnányi Ernő emlékére [In Memory of Ernst von Dohnányi], was directed by Anna Mérei and hosted by András Batta. See: https://port.hu/adatlap/film/tv/ dohnanyi-erno-emlekere/movie-61827 (accessed November 23, 2020).

${ }^{2}$ Dohnányi was present at all of these five concerts - either personally or through one of his transcriptions.

${ }^{3}$ The program of the concerts was released by the organizing committee in a booklet which also lists the patrons and the members of the organizing committee. N. N., Schubert-Zeneünnepély halálának századik évfordulója alkalmából [Schubert: Music festival on the occasion of the 100th anniversary of his death] (Budapest: A Schubert-centenárium rendezö bizottsága kiadása, 1928).
} 
ballet production entitled $A$ múzsa csókja (The Kiss of the Muse) and based on a storyline written by Dohnányi's wife, actress and dancer Elsa Galafrés (see Appendix). ${ }^{4}$

Following its stage premiere, the ballet $A$ múzsa csókja was also performed in the Great Hall of the Music Academy: on January 6, 1929 the Philharmonic Orchestra performed it again, this time conducted by Dohnányi. The other Schubert transcription, the orchestration of the FMinor Fantasy, was performed on the last orchestral evening of the Schubert Centenary, on November 26, 1928 by the Orchestra of the local Philharmonic Society, conducted by the orchestrator himself. ${ }^{5}$ Unsurprisingly, the ballet $A$ múzsa csókja, first performed at the festival concert, aroused more interest and received more echoes from the metropolitan press than the orchestration of the Piano Fantasy which was, at the time, performed rather sporadically in Budapest. ${ }^{6}$ We may add that, in the first half of the twentieth century, Schubert's piano works in general, including the pieces from the piano cycle Moments musicaux, featured quite rarely in public concerts. ${ }^{7}$ This, of course, can also be explained by the fact that these intimate compositions were primarily intended for domestic music-making and not specifically for concert hall performances. Heinrich Berté most certainly inserted Schubert's piano pieces in his operetta Das Dreimäderlhaus (1916), a work that already had hundreds of performances in Budapest by the $1920 \mathrm{~s},{ }^{8}$ in order to promote these pieces. It is conceivable that Berté's popular Schubert operetta could also serve as a model for the Dohnányis for the ballet composition A múzsa csókja. However, the Hungarian eurhythmical currents of the first half of the century also favored Schubert's works: in the program of the performances given by Valéria Dienes' School of Orchestics, we often encounter choreographies based on Schubert's piano works. ${ }^{9}$ Even though

\footnotetext{
${ }^{4}$ The storyline written for the ballet The Kiss of the Muse by Elsa Galafrés was published in a joint volume with the libretto of Schubert's one-act Singspiel Die Verschworenen, in a series of volumes dedicated to the libretti of the pieces presented by the Budapest Opera House. N. N., Schubert: Cselre-cselt (J. F. Castelli)/A múzsa csókja (Dohnányi-Galafrés Elsa). Operaházi szövegkönyvek 7. (Debrecen-Budapest: Csáthy Ferenc Egyetemi Könyvkereskedés és Irodalmi Vállalat Rt, 1928), 68-79.

${ }^{5}$ N. N., Schubert - Zeneünnepély, 3-12.

${ }^{6}$ According to the "Budapest Concerts database" (henceforth referred to as "BCD"), operated by the Archives for 20th21st-Century Hungarian Music of the Institute for Musicology RCH, between 1900 and 1928 Schubert's Fantasy was performed only three times in Budapest. Cf. <http://db.zti.hu/koncert/koncert_Kereses.asp> (accessed on January 19, 2021).

${ }^{7}$ According to BCD, the piano cycle, or one of its pieces, was performed a total of twelve times between 1900 and 1928. Although the brief description of the Dohnányi orchestration, published without signature in the October 15, 1930 issue of the review A Zene, described the Moments musicaux as "one of the most popular pieces in the piano literature," the data regarding concert hall performances do not necessarily confirm this. N. N., "Hangversenymüsoraink ismertetése" [Our concert programs], A Zene 12/2 (October 5, 1930), 22.

${ }^{8}$ The popularity of the operetta is confirmed by the fact that in 1919 , i.e. three years after the Budapest premiere, the 200th performance was celebrated. N. N., "A Három a kisleány jubileuma” [The anniversary of Das Dreimäderlhaus], Budapesti Hírlap 39/103 (November 2, 1919), 6.

${ }^{9}$ Ágnes BORECZKY, “Más művészet - új közönség. A mozdulatművészet és a korabeli társadalom” [Other art - new audience. Movement art and contemporary society]," in Mozdulat - magyar mozdulatmüvészet a korabeli társadalom és müvészet tükrében [Movement - Hungarian free dance in the light of contemporary society and art], ed. by László BEKE, András NÉMETH and Gabriella VINCZE (Budapest: Gondolat Kiadó, 2013), 59 and 69. The same study mentions, for example, Valéria Dienes's choreography based on Margit Bethlen's fairy tale Fehér királyleány [White princess], which also used, among others, Schubert's Wanderer Fantasy. BORECZKY, "Más müvészet - új közönség," 89. The legacies preserved at the Dance Archives of the Hungarian Theater Museum and Institute (e.g. Margit Riedl, Lili Kállai, Mária Mirkovszky, Andor Tiszay) contain a number of programs and playbills also testifying to the very same preference for Schubert's piano music. I hereby express my gratitude to Tamás Halász, staff member of the Dance Archives, for this information.
} 
these performances addressed a narrower public, the actress and dancer Elsa Galafrés must have certainly been familiar with them.

The idea of orchestrating and staging the Moments musicaux cannot be considered unprecedented, as in the first half of the twentieth century a number of ballets were produced, using the orchestrated version of well-known piano pieces. Such was the case with Les Sylphides (Chopiniana, 1909) made for Serge Diaghilev's Ballets Russes and consisting of Chopin's piano pieces orchestrated by Glazunov. Schumann's piano cycles Le Carnaval (1910) and Papillons (1914) were also staged in an orchestrated version. ${ }^{10}$ In addition, in 1927, i.e. the year preceding the premiere of the Dohnányi-Galafrés production, Diaghilev's ensemble had a series of guest performances at the Municipal Theater (Városi Színház), between November 28 and December 8. Their program included - in addition to the already mentioned Le Carnaval - the stage adaptation of Carl Maria von Weber's piano work, entitled Aufforderung zum Tanz. ${ }^{11}$ The Dohnányis may have been aware of the Ballets Russes' tour in Hungary as well as the stage adaptations in their repertoire; they may even have been present at some of these guest performances. Consequently, it is highly conceivable that the performance of the foreign company may also have influenced the idea of preparing a ballet production based on Schubert instrumentations.

Dohnányi had a key role in the concert hall presentation of Schubert's works for the piano, as the compositions of the Viennese master had been abundantly featured in his piano repertoire since 1897. ${ }^{12}$ The pieces of the Moments musicaux piano cycle had been present in Dohnányi's repertoire since 1912; most often included in his concerts were no. 2 (in A major) and no. 3 (in F minor). ${ }^{13}$ The Philharmonic Society Orchestra, i.e. the ensemble led by Dohnányi, had Schubert in the repertoire from the very beginning of their operation; most often they played the "Unfinished" Symphony (D. 759) and the "Great" Symphony in C Major (D. 944), but the Mass in E-flat Major (D. 950), the symphony no. 6 in C major (D. 589), the Rosamunda ballet music, and the Rosamunda overture were also performed once. ${ }^{14}$ Similarly to them, the Orchestra of the Capital, established in 1923, only performed the best-known Schubert works, like the "Unfinished" Symphony and the Rosamunda overture. ${ }^{15}$ Dohnányi began conducting Schubert much later than he included the composer's work in his repertoire as a pianist: he first conducted in

\footnotetext{
${ }^{10}$ Rebecca HARRIS-WARRICK, Noël GOODWIN and John PERCIVAL, "Ballet," in Oxford Music Online <https://doi. org/10.1093/gmo/9781561592630.article.46700> (accessed on March 2, 2021).

11“Cs. A.” [CSERNA, Andor], “Az orosz balett a Városi Színházban” [The Ballets Russes at the City Theater], Pesti Napló 78/272 (November 30, 1927), 15. On the appearances of the Ballets Russes in Budapest, 1927, see also Francisco J. GIMÉNEZ-RODRÍGUEZ, "De Falla’s Hungarian Success: A háromszögletü kalap (1928),” Studia Musicologica 59/3-4 (December, 2018), 314-315.

${ }^{12}$ Ilona KOVÁCS, “Dohnányi Ernő zongoramüvészi pályája. I. rész: 1897-1921” [Ernst von Dohnányi’s career as a pianist. Part I: 1897-1921], in Dohnányi Évkönyv 2005, ed. by Márta SZ. FARKAS (Budapest: MTA Zenetudományi Intézet, 2006), 85.

${ }^{13}$ Ibid.

${ }^{14}$ The repertoire of the Philharmonic Society was published by Ferenc Bónis in a CD-ROM attached to his volume released in 2005. Ferenc BÓNIS, A Budapesti Filharmóniai Társaság százötven esztendeje, 1853-2003 [One hundred and fifty years of the Budapest Philharmonic Society, 1853-2003] (Budapest: Balassi Kiadó, 2005).

${ }^{15} \mathrm{I}$ am grateful to István Mali for providing the digital list, prepared for internal use, with the repertoire of the Orchestra of the Capital.
} 
front of the Philharmonic the "Unfinished" Symphony (on January 7, 1923), and a year later the "Great" Symphony in C Major (on October 26, 1924). Until 1928, Dohnányi had conducted only these two compositions by Schubert, and his personal music library only contained these two scores by the Austrian master. ${ }^{16}$ However, we can safely assume that these were not the only orchestral works by Schubert he was familiar with.

Orchestrated "with Schubertian heart" - Viktor Papp used these words to describe The Kiss of the Muse, i.e. Dohnányi's orchestration of the Moments musicaux. ${ }^{17}$ The question rightly arises, however, to what extent the Budapest audience - including the music critics - may have been familiar with Schubert's orchestral works and his orchestration practices at this time. The knowledge of the musically educated concerning Schubert's style is revealed by Viktor Papp's thoughts published in the review Új Nemzedék:

"With Schubertian heart" - there is no higher appraisal we could use here. The absence of Schubertian knowledge is natural, because it is well known that among the greatest masters, Schubert was relatively untrained. ${ }^{18}$

According to the lines above, the reviewer seems to have considered Dohnányi's orchestration to be in appropriate style, yet in terms of craftsmanship he placed it above Schubert's own treatment of the orchestra. We might add that Papp's remark, which is obviously controversial today, did not primarily refer to the orchestration. His critical attitude towards Dohnányi for personal reasons actually documents that Schubert's music was not yet known in concert life. Papp's line of thought, clearly biased in favor of Dohnányi for personal reasons, ${ }^{19}$ actually documents that Schubert's music was not yet known in concert life. Against this background, questions are to be answered as to what extent the orchestrations of Dohnányi can be considered Schubertian and why exactly he chose these two particular works.

It is possible that the performance issues of the piano compositions he dealt with during the Schubert centenary may have inspired Dohnányi to prepare the orchestrations. He first performed the Fantasy in F Minor, for piano four hands, on October 18, 1928 in Timişoara and on the following day in Arad with his student, Edward Kilényi. ${ }^{20}$ The latter was only eighteen years

\footnotetext{
${ }^{16}$ Anna LASKAI, “Ernő Dohnányi’s Library and Music Collection,” Studia Musicologica 69/1-2 (June 2018), 97-206.

${ }^{17}$ Viktor PAPP, “Schubert: 'Cselre-cselt,' ‘A múzsa csókja.' Fôpróba az Operaházban” [Schubert: “Die Verschworenen,” “The Kiss of the Muse.” Dress rehearsal at the Opera House], Új Nemzedék 10/263 (November 20, 1928 ), 8.

${ }^{18}$ Ibid.

${ }^{19}$ Viktor PAPP was a personal acquaintance and a friend of Dohnányi who also published a number of writings about the composer. See, for instance, id., "Dohnányi az operaíró" [Dohnányi, the composer of operas], Zenei Szemle 6/3 (July 1922), 36-38.; id., Arcképek a magyar zenevilágból [Portraits from Hungarian musical life] (Budapest: Stádium, 1925); id., Dohnányi Ernő. (Arckép) [E. von D. (A portrait)] (Budapest: Stádium Sajtóvállalat, 1927); id., “Dohnányi Ernő, az ember” [E. D., the man], Zenei Szemle 11/9-10 (October-November 1927), 215-218.; id., Dohnányi Erno” és Szegedi miséje: Missa in dedicatione Ecclesiae [Ernst von Dohnányi and his Szeged Mass: Missa in dedicatione ecclesiae] (Debrecen, Budapest: Csáthy, [1930]).

${ }^{20}$ Ilona KOVÁCS, “Dohnányi Ernő zongoramüvészi pályája. II. rész: 1921-1944” [Ernst von Dohnányi’s career as a pianist. Part II: 1921-1944], in Dohnányi Évkönyv 2006/7, ed. by Márta SZ. FARKAS and László GOMBOS (Budapest: MTA Zenetudományi Intézet, 2006), 349.
} 
old then; however, he encountered Dohnányi again much later, during his years of emigration. ${ }^{21}$ They played the Fantasy in F Minor again in public in the United States, almost three decades later, on June 7,1954 , at which time a sound recording of their performance was made. Although this recording captures the playing of the old master, we can still assume that it reflects the features of his earlier Schubert interpretation. And in spite of the fact that this rendering obviously due to the texture - gives a "symphonic" dimension to certain segments of the composition, it is quite possible that the idea of an orchestral transcription of the piece for piano four hands first appeared during the rehearsals Dohnányi had with Kilényi in 1928, as the manuscript score preserved in the Music Collection of the Philharmonic Society is dated November $15 .^{22}$

Bálint Vázsonyi wonders whether the piano performance could have inspired the transcription of the Moments musicaux, also emphasizing that it was Dohnányi's performance that encouraged Elsa Galafrés to develop the idea of the ballet. ${ }^{23}$ The brief description, released in the review $A$ Zene, also seems to indicate a similarity between Dohnányi's Schubert interpretation on the piano and his orchestration. It reads: "Dohnányi, the brilliant interpreter of Schubert's genius, transposed the lavish colors of his unsurpassed touch into the very stylish instrumentation of the six small pieces, conceived in Schubert's technique. ${ }^{\text {" } 24}$ It is remarkable, however, that the reviewer thought of discovering the features - the colors - of Dohnányi's touch in the instrumentation, with which he certainly wanted to draw a parallel between the musical motifs emphasized in Dohnányi's piano performance by his touch and the scoring he used for his orchestration. Only a single piece from the Moments musicaux, the movement no. 2 in A-flat major, has survived in a sound recording with Dohnányi. Made in the United States in the early 1920s, it preserves Dohnányi's performance on a player piano roll; ${ }^{25}$ however, this recording technique is unable to reproduce the features of Dohnányi's colorful piano touch described by the critic.

Following the premiere of Dohnányi's orchestration of the Fantasy in F Minor, Aladár Tóth summarized in the journal Pesti Napló his thoughts concerning the piano interpretation and the orchestration:

Dohnányi was already prompted in the selection of the work by Schubert to be orchestrated by the most delicate artistic tact. The Fantasy in F Minor conceals poetic contents that cannot unfold with complete freedom among the often very limited formal possibilities of the texture for piano four hands. In these compositions, we almost always feel the shackles of technical awkwardness. Dohnányi's orchestration, thus, brought a certain liberation of the Fantasy's poetic contents; of course,

\footnotetext{
${ }^{21}$ Veronika KUSZ, A Wayfaring Stranger. Ernst von Dohnányi's American Years, 1949-1960 (Oakland, California: University of California Press), 37.

${ }^{22}$ There are two press marks on the score. According to the inventory of the Music Collection made by Béla Csuka, the number "D24" may refer to an earlier cataloging, while the other reference number (640) might have been given to the score during a later revision.

${ }^{23}$ VÁZSONYI, Dohnányi, 213. In this case, too, the idea may arise that the eurhythmical performances with piano accompaniment mentioned above may have had an influence on Galafrés' creation of the ballet.

${ }^{24}$ N. N., "Hangversenymüsoraink ismertetése" [Our concert programs], A Zene 12/2 (October 5, 1930), 22.

${ }^{25}$ Ampico-recording number $61063 \mathrm{H}$ has not been reissued on any modern data carrier. See, Imre PODHRADSZKY, “The Works of Ernő Dohnányi," Studia Musicologica 6 (1964), 368. I owe Ferenc János Szabó a debt of gratitude for the information concerning the recording.
} 
not a Schubertian liberation, only a Schubert-like liberation. It is a brilliant achievement in orchestration, containing the most artistic economy of timbres. If, for example, Dohnányi has a theme first played on woodwinds and then on strings, this serves not only the interests of variety, but it also is an explanation of the inner form of the composition. ${ }^{26}$

Compared to Viktor Papp's previously quoted phrase "with Schubertian heart," Aladár Tóth was somewhat more cautious by describing the orchestration not as "Schubertian," but only as "Schubert-like." At the same time, he also pointed out that Dohnányi made the "poetic contents" and form of Schubert's composition more understandable through the orchestration. There is no doubt, however, that a good performance of the Fantasy in F Minor, even in its original version for piano four hands, can reach the level of artistic perfection, and in my opinion the performance by Dohnányi and Kilényi was certainly such a rendering. Aladár Tóth's suggestion that the work was liberated through the orchestration may also refer to the fact that Dohnányi's orchestration conveys a concert hall-filling sonic experience in comparison with the otherwise intimate four-hand piano version. By the way, Viktor Papp similarly viewed the orchestrated Fantasy in F Minor as valuable; according to him, too, Dohnányi's orchestration increased the value of the composition:

The colorful, clearly logical orchestration of the Fantasy in F Minor (op. 103), written for piano four hands, is surprising. All the themes, motifs and piano phrases are transposed in the right place within the orchestra. The orchestral arrangement increased the Schubertian value of the work, which is rarely the case with transcriptions. ${ }^{27}$

Here Viktor Papp obviously uses the term "transcription," which implies the possibility of changes to the original work, as a synonym for "orchestration." But it is clear that Dohnányi did not change Schubert's composition while he orchestrated it.

Only Viktor Lányi thought to discover a parallel with another actual work by Schubert: Dohnányi's instrumentation reminded the music critic of the journal Pesti Hirlap of Schubert's "Unfinished" Symphony, or rather its atmosphere:

The notion of an orchestration was a very fortunate idea of Dohnányi, and the way he completed the idea shows the great knowledge of style and delicate sense of orchestra of this congenial performer of Schubert. In the magnificent score, the solo instruments sing according to Schubert's heart, and we often feel as if the dramatic character, the deep, romantic Weltschmerz of the "Unfinished" Symphony emanated from this beautiful work, brilliantly brought to new life. ${ }^{28}$

Lányi's words, "the solo instruments sing according to Schubert's heart," echo the phrase "Schubertian heart" employed by Viktor Papp. There are indeed similarities in the mood of the two compositions in question and in the use of solo instruments, especially the woodwinds. Although the kinship with the atmosphere of the Schubert symphony was only articulated by Viktor Lányi, it is clear that the last two symphonies by Schubert may have served as the primary model for both of Dohnányi's orchestrations.

\footnotetext{
26“(T-th)” [Aladár TÓTH], “A Schubert-ünnep” [Celebrating Schubert], Pesti Napló 79/269 (November 27, 1928 ), 14.

27“P. V.” [Viktor PAPP], “Schubert centenárium” [Schubert centenary], Új Nemzedék 10/269 (November 27, 1928 ), 8.

${ }^{28}$ Viktor LÁNYI, “A Filharmóniai Társaság Schubert-ünnepe” [The Schubert festival of the Philharmonic Society], Pesti Hírlap 50/269 (November 27, 1928), 14.
} 


\section{SCHUBERT'S SYMPHONIC WORKS IN BUDAPEST: A BROADER PERSPECTIVE}

In addition to the presence of Schubert's works in the concert life of the Hungarian capital, it is worth examining how many more times both Dohnányi orchestrations were included in the repertoire of the Philharmonic Society during Dohnányi's presidency there, as well as in the programs of other symphony orchestras. According to the "Budapest Concerts Database," accessible at the website of the Archives for 20th-21st-Century Hungarian Music of the Budapest Institute for Musicology, the orchestral transcription of the Fantasy in F Minor was only played on two occasions after its first performance, while the orchestral version of The Kiss of the Muse was performed on a total of six occasions in Budapest (see Table 1). It is obvious that Dohnányi's orchestration of the Moments musicaux was played more often by the various ensembles. However, while the Orchestra of the Capital performed it five times, Dohnányi's ensemble only programmed one of the transcriptions, and the performance was directed by János Ferencsik, i.e. not by Dohnányi himself. As the first row in the table reveals, Felix Mottl's orchestration of the Fantasy in F Minor, which will be discussed in detail below, was performed in 1929 by the Orchestra of the Capital, presumably in relation to the Schubert anniversary of the previous year.

Table 1. Schubert instrumentations on the programs of the symphony orchestras in Budapest

\begin{tabular}{|c|c|c|}
\hline Date and Place & Orchestration & Orchestra, Conductor \\
\hline $\begin{array}{l}\text { June } 27,1929, \\
\text { City Park }\end{array}$ & Fantasy in F Minor (Mottl) & $\begin{array}{l}\text { Orchestra of the Capital, } \\
\text { Dezsö Bor }\end{array}$ \\
\hline \multirow[t]{2}{*}{$\begin{array}{l}\text { Oct } 29,1930, \\
\text { Redoute }\end{array}$} & $\begin{array}{l}\text { Fantasy in F Minor } \\
\text { (Dohnányi) }\end{array}$ & \multirow[t]{2}{*}{$\begin{array}{c}\text { Orchestra of the Capital, } \\
\text { Dezső Bor }\end{array}$} \\
\hline & $\begin{array}{l}\text { Moments musicaux } \\
\text { (Dohnányi) }\end{array}$ & \\
\hline $\begin{array}{l}\text { Oct } 29,1935 \text {, } \\
\text { Redoute }\end{array}$ & $\begin{array}{l}\text { Moments musicaux } \\
\text { (Dohnányi) }\end{array}$ & $\begin{array}{l}\text { Orchestra of the Capital, } \\
\text { Dezsö Bor }\end{array}$ \\
\hline $\begin{array}{l}\text { June } 6,1937 \\
\text { Garden of the Ministry of the Interior }\end{array}$ & $\begin{array}{l}\text { Moments musicaux } \\
\text { (Dohnányi) }\end{array}$ & $\begin{array}{c}\text { Budapest Philharmonic } \\
\text { Orchestra, } \\
\text { János Ferencsik }\end{array}$ \\
\hline $\begin{array}{l}\text { July } 24,1937 \text {, Garden of the } \\
\text { Metropolitan Gallery; } \\
\text { Concert celebrating Dohnányi's } \\
\text { 60th birthday }\end{array}$ & $\begin{array}{l}\text { Moments musicaux } \\
\text { (Dohnányi) }\end{array}$ & $\begin{array}{c}\text { Orchestra of the Capital, } \\
\text { Dezső Bor }\end{array}$ \\
\hline $\begin{array}{l}\text { Aug } 14,1940, \\
\text { Garden of the Metropolitan Gallery }\end{array}$ & $\begin{array}{l}\text { Moments musicaux } \\
\text { (Dohnányi) }\end{array}$ & $\begin{array}{l}\text { Orchestra of the Capital, } \\
\text { Béla Csilléry }\end{array}$ \\
\hline $\begin{array}{l}\text { Aug 28, } 1943 \text {, } \\
\text { Garden of the Metropolitan Gallery }\end{array}$ & $\begin{array}{l}\text { Moments musicaux } \\
\text { (Dohnányi) }\end{array}$ & $\begin{array}{l}\text { Orchestra of the Capital, } \\
\text { Dezsö Bor }\end{array}$ \\
\hline $\begin{array}{l}\text { Jan } 14,1956 \\
\text { Liszt Music Academy }\end{array}$ & Fantasy in F minor (Dohnányi) & $\begin{array}{l}\text { Hungarian State Orchestra, } \\
\text { László Somogyi }\end{array}$ \\
\hline
\end{tabular}


The reason why Dohnányi did not include his transcriptions on later programs of the Philharmonic is not clear, but he certainly programmed his orchestration of the Fantasy in F Minor in the concerts he gave as a guest conductor in the Netherlands in 1929. Based on the collection of playbills preserved within the Dohnányi Collection of the National Széchényi Library, Dohnányi conducted Mengelberg's Concertgebouw Orchestra on four occasions between January 29 and February 3, 1929. Dohnányi's orchestration of the Fantasy in F Minor was performed on two of these occasions - on January 29 in Haarlem and on February 3 in Amsterdam. But this may not have been the only time that the orchestration in question was performed abroad, as from a letter preserved in Bálint Vázsonyi's legacy, it seems that the internationally acclaimed conductor Otto Klemperer asked for the orchestral material of Dohnányi's transcription. The letter addressed to Dohnányi by the firm Rózsavölgyi and Co. on August 25, 1933 reads: "Klemperer ... personally took over the orchestral material from our company today, as he will conduct it during his concerts to be given both in Europe and America in the next concert season." ${ }^{29}$ During this period, Klemperer was indeed the guest conductor of several ensembles, as in 1933, after the Nazis came to power in Germany, he had to leave the country because of his Jewish origins. ${ }^{30}$ In the same year, he visited Budapest several times as a guest conductor, and on these occasions he conducted the Budapest Concert Orchestra. $^{31}$ At this time it cannot be confirmed whether Klemperer actually conducted the Dohnányi instrumentation at any point either in Hungary or abroad.

\section{A COMPARISON OF THE TWO ORCHESTRATIONS}

Comparing Dohnányi's two orchestrations with the ones made by other nineteenth- and twentieth-century composers, one may begin by saying that Dohnányi's orchestration of the Fantasy in F Minor - employing double woodwinds, three trombones, timpani, triangle, and strings with a solo violin - respects the Classical, early Romantic, rather simple orchestral scoring of the Schubert symphonies (see Table 2). ${ }^{32}$ In his orchestration of the Moments musicaux, however, Dohnányi used slightly more varied forces, consisting of pairs of woodwinds, four horns (instead of the two horns commonly used by Schubert), two trumpets, three trombones, timpani, triangle, and a side drum. In movements 4 and 6 , the instruments of the string section (with the exception of the double bass) alternately play solo and ripieno. The most peculiar feature of Dohnányi's

\footnotetext{
${ }^{29}$ The letter is preserved in the Vázsonyi Collection of the Archives for 20th-21st-Century Hungarian Music of the Institute for Musicology RCH. Its shelfmark, given by Vázsonyi, is H00-060.

${ }^{30}$ Michael H. KATER, The Twisted Muse: Musicians and Their Music in the Third Reich (New York-Oxford: Oxford University Press, 1997), 79-80.

${ }^{31}$ Bartók's Piano Concerto No. 2 was first performed in Budapest by Lajos Kentner and the Budapest Concert Orchestra, conducted by Klemperer, on June 2, 1933. Attila BOROS, Klemperer Magyarországon [Klemperer in Hungary] (Budapest: Zenemúkiadó, 1984), 14. See also, Lóránt LADÁNYI, “Otto Klemperer Budapesten tudta meg, hogy elbocsátották a berlini Operától” [Otto Klemperer learned in Budapest that he had been fired from the Berlin Opera], Ujság 9/125 (June 3, 1933), 3.

${ }^{32}$ The Symphony in E major (D729), listed as [No. 7], is an exception among Schubert's symphonies, for the composer, unusually, prescribed there four horns and three trombones, respectively. However, this symphony survived in a draft, so it could not be part of the concert repertoire of the period in question. According to BCD, this Schubert symphony was first performed in the Hungarian capital only in the 1970s. Cf.: MZA BHA ID_16086, ID_16087.
} 
Table 2. The scoring of Schubert's symphonies and of the orchestral transcriptions by Ernő Dohnányi, Ernst Rudorff, and Felix Mottl

\begin{tabular}{|c|c|c|c|c|c|c|c|c|c|c|c|}
\hline Composer & Piece & FI & $\mathbf{O b}$ & CI & $\mathrm{Fg}$ & Cor & $\mathrm{Tr}$ & Trb & Timp/Perc. & Archi & Other \\
\hline \multirow[t]{9}{*}{ Schubert } & Symphony No. 1 in D Major, D. 82 & 1 & 2 & 2 & 2 & 2 & 2 & - & $\mathrm{D}, \mathrm{A}$ & + & - \\
\hline & $\begin{array}{l}\text { Symphony No. } 2 \text { in B-flat Major, } \\
\text { D. } 125\end{array}$ & 2 & 2 & 2 & 2 & 2 & 2 & - & $\mathrm{B}, \mathrm{F}$ & + & - \\
\hline & $\begin{array}{l}\text { Symphony No. } 3 \text { in D Major, } \\
\text { D. } 200\end{array}$ & 2 & 2 & 2 & 2 & 2 & 2 & - & D, A & + & - \\
\hline & $\begin{array}{l}\text { Symphony No. } 4 \text { in C Minor, } \\
\text { D. } 417\end{array}$ & 2 & 2 & 2 & 2 & 4 & 2 & - & D, A & + & - \\
\hline & $\begin{array}{l}\text { Symphony No. } 5 \text { in B-flat Major, } \\
\text { D. } 485\end{array}$ & 1 & 2 & - & 2 & 2 & - & - & - & + & - \\
\hline & $\begin{array}{l}\text { Symphony No. } 6 \text { in C Major, } \\
\text { D. } 589\end{array}$ & 2 & 2 & 2 & 2 & 2 & 2 & - & $C, G$ & + & - \\
\hline & $\begin{array}{l}\text { Symphony [No. 7] in E Major, } \\
\text { D. } 729\end{array}$ & 2 & 2 & 2 & 2 & 4 & 2 & 3 & E, B & + & \\
\hline & $\begin{array}{l}\text { Symphony No. } 8 \text { in B Minor, } \\
\text { "Unfinished," D. } 759\end{array}$ & 2 & 2 & 2 & 2 & 2 & 2 & 3 & B, F sharp & + & - \\
\hline & $\begin{array}{l}\text { Symphony No. } 9 \text { in C Major, } \\
\text { "Great," D. } 944\end{array}$ & 2 & 2 & 2 & 2 & 2 & 2 & 3 & $C, G$ & + & - \\
\hline $\begin{array}{l}\text { Schubert-Dohnányi } \\
\text { (1928) }\end{array}$ & $\begin{array}{l}\text { Fantasy in F Minor for Piano Duet, } \\
\text { D. } 940\end{array}$ & 2 & 2 & 2 & 2 & 2 & 2 & 3 & $\mathrm{C}, \mathrm{F}$, triangle & + VI solo & - \\
\hline $\begin{array}{l}\text { Schubert-Dohnányi } \\
\text { (1928) }\end{array}$ & Moments musicaux, D. 780 & 2 & 2 & 2 & 2 & 4 & 2 & 3 & $\begin{array}{l}\text { C, F, D, A triangle, side } \\
\text { drum }\end{array}$ & $\begin{array}{l}+ \text { (no. 6: soli and } \\
\text { ripieno) }\end{array}$ & Arpa \\
\hline Ernst Rudorff (1870) & $\begin{array}{l}\text { Fantasy in F Minor for Piano Duet, } \\
\text { D. } 940\end{array}$ & 2 & 2 & 2 & 2 & 4 & 2 & 3 & $\mathrm{C}, \mathrm{F}$ & - & - \\
\hline $\begin{array}{l}\text { Schubert-Mottl } \\
\text { (1897) }\end{array}$ & $\begin{array}{l}\text { Fantasy in F Minor for Piano Duet, } \\
\text { D. } 940\end{array}$ & $2+1$ & 2 & 2 & 2 & 4 & 2 & 3 & $\mathrm{C}, \mathrm{F}$, triangle & + Vlc solo & Arpa \\
\hline
\end{tabular}


orchestration is the use of harp, which cannot be considered "Schubertian," as the Viennese composer did not use this instrument at all in his symphonies and overtures, not even in the Rosamunda overture, the musical material of which is actually identical to the overture of Schubert's incidental music for Die Zauberharfe. ${ }^{33}$ According to the above, it can be concluded that the scoring of the Fantasy in F Minor is closer to that in Schubert's works than that of the Moments musicaux, orchestrated "with Schubertian heart," as Viktor Papp put it.

As a matter of fact, the harp also appears in the orchestration of the Fantasy in F Minor that the Austrian composer-conductor Felix Mottl composed on the occasion of the 1897 Schubert centenary. For this transcription, Mottl used a larger orchestra than Schubert would have employed - this was probably also connected to the fact that Mottl was one of the most important Wagner conductors of his time. It is unclear whether Dohnányi knew this earlier orchestration; in any case several orchestral transcriptions of Schubert's songs made by Mottl were featured in the Philharmonic Society's program earlier. ${ }^{34}$ On the other hand, Dohnányi may have been familiar with the transcription, completed in 1870, by the work's first orchestrator, Ernst Rudorff - the latter offered young Dohnányi a job at the Berlin Musikhochschule in 1905. ${ }^{35}$ Rudorff's scoring, like Dohnányi's, applies the instrumental forces of the Schubert symphonies with the difference that it uses two horns instead of four, but - unlike Dohnányi and Mottl - he does not use the triangle (Table 2). ${ }^{36}$

In both of his orchestrations, Dohnányi included the triangle, an instrument not used at all by Schubert in his symphonies. This percussion instrument appears in the orchestral texture of the transcriptions as a kind of coloring, as does the harp, which was also alien to Schubert's orchestra. The harp appears in the Allegro vivace and Trio sections of the Fantasy in F Minor; in the case of the Moments musicaux, it is present in four of the six pieces (movements 1, 2, 4 and 6), most often providing the chordal accompaniment in small segments lasting only a few measures. It is only in the middle section of the second movement that it deviates from the chordal movement, where it plays an arpeggio accompaniment.

In the 19th and 20th centuries, a number of transcriptions were made of Schubert's Moments musicaux (the entire piano cycle or some of its movements); most of them were typically intended for a solo instrument or chamber ensemble with piano accompaniment. ${ }^{37}$ A significantly smaller number of arrangements for symphony or string orchestra were exclusively based on the cycle's quite popular third movement, the Air russe in F minor. ${ }^{38}$ To the best of our

\footnotetext{
${ }^{33}$ See, Benjamin ORY, “Mysterious Attributions: Reception of Die Zauberharfe," blog entry (May 13, 2016) available at <https://library.stanford.edu/blogs/stanford-libraries-blog/2016/05/mysterious-attributions-reception-die-zauberharfe> (accessed on November 23, 2020).

${ }^{34}$ BÓNIS, A Budapesti Filharmóniai Társaság, attachment.

${ }^{35}$ VÁZSONYI, Dohnányi, 110.

${ }^{36}$ The score of Rudorff's orchestration was published by Simrock in 1870. A digital version is accessible at the Leon Levy Digital Archives of the New York Philharmonic, under <https://archives.nyphil.org/index.php/artifact/a379d810-82524004-b21a-5b6b80779a7f-0.1/fullview\#page/66/mode/2up> (accessed on October 20, 2020).

${ }^{37}$ The Petrucci Music Library lists a total of fifty-four arrangements of the Moments musicaux. See, <https://imslp.org/ wiki/Moments_musicaux,_D.780_(Schubert,_Franz)> (accessed on November 18, 2020).

${ }^{38}$ The Air russe was arranged by Ferdinand Thieriot (1838-1919) for string orchestra (n.d.), by L. Girard for symphonic orchestra (1876), by Richard E. Hildreth (1867-1941) for theater orchestra (1910), by Leopold Stokowski (1882-1977) for symphonic orchestra (a sound recording was made in 1922) and by Béla Bánfalvi (1954-) for string orchestra (n.d.).
} 
current knowledge, Dohnányi's orchestration is the only complete version conceived for symphony orchestra.

A series of arrangements for orchestra were made of the Fantasy in F Minor, during the twentieth century, in addition to the ones already mentioned above. ${ }^{39}$ For some strange reason, however, none of the CD booklets or shorter descriptions that I know of mentions Dohnányi's orchestration of the Fantasy in F Minor. ${ }^{40}$ The most interesting of these, in terms of the reworking itself, is Kabalevsky's arrangement, made in 1961, which transfigured the Fantasy in F Minor into a three-movement piano concerto. ${ }^{41}$ Though somewhat liberated from the original stylistic environment, this idea could easily have occurred to the pianist-composer Dohnányi, too, but he preferred to create a symphonic work closer to Schubert - perhaps a new Schubert symphony?

\section{DOHNÁNYI'S SCHUBERT ORCHESTRATIONS: A CLOSER LOOK}

Did Dohnányi want to promote Schubert's works virtually unknown in the period's concert life, or did he want to produce completely new works in Schubert's style? Through his orchestration, did Dohnányi possibly want to recreate or "reconstruct" non-existent, never written, or "unfinished" orchestral works, reflecting Schubert's style? These questions can be answered based on the memoirs of the composer's second wife Elsa Galafrés, according to whom Dohnányi was not at all fond of competitions and he deliberately did not take part in the competition for the completion of the "Unfinished" Symphony. ${ }^{42}$ It also appears from the memoirs that Dohnányi considered explicitly harmful, and therefore avoided, interfering with the works of composers he considered "immortal." 43

\footnotetext{
${ }^{39}$ The Petrucci Music Library lists a total of twenty-one arrangements of the Fantasy in F Minor. See, <https://imslp.org/ wiki/Fantasie_in_F_minor\%2C_D.940_(Schubert\%2C_Franz)> (accessed on November 18, 2020). Here are the arrangements for symphony orchestra, in chronological order: 1870: Ernst Rudorff (1840-1916); 1897: Felix Mottl (1856-1911); 1928: Ernst von Dohnányi (1877-1960); 1940: Willem van Otterloo (1907-1978); 1961: Dmitry Borisovich Kabalevsky (1904-1987); 1984: Roman Pawloswski (1965-); 2016: Kevin Vincent Halpin; 2019: Benjamin Yusopov (1962-).

${ }^{40}$ See, for instance, Christopher H. GIBBS, “About Schubert's Arrangers: Mottl, Liszt, Brahms, Joachim” at <https:// americansymphony.org/concert-notes/about-schuberts-arrangers-mottl-liszt-brahms-joachim/> (accessed on November 10, 2020), or Klaus ZEHNDER-TISCHENDORF's "Preface" to Ernst Rudorff's orchestration, reproduced at the website of Musikproduktion Jürgen Höflich, which does mention some of the other orchestrators, too. <https:// repertoire-explorer.musikmph.de/wp-content/uploads/vorworte_prefaces/373.html> (accessed on November 10, 2020).

${ }^{41}$ Kabalevsky made this arrangement for pianist Emil Gilels. See Jean-Yves DUPERRON's brief text, presenting the recording of Kabalevsky's Complete Piano Concertos (CPO 777658-2, August 2012), reproduced at <http://www. classicalmusicsentinel.com/KEEP/keep-kabalevsky-concertos.html> (accessed on November 24, 2020).

${ }^{42}$ Elsa GALAFRÉS, Lives. . . Loves. . . Losses (Vancouver: Versatile, 1973), 339.

43" He labelled as a pernicious mistake this intervention in the work of an immortal, to which he would not lend a hand." - (Versatile, 1973). The competition mentioned by Elsa Galafrés, brought to life in order to motivate the completion of Schubert's symphony, was in fact organized by the Anglo-American Columbia Record Company and the Gesellschaft der Musikfreunde in Wien. For more about the competition, see Malcolm MACDONALD, "Czesław Marek and his Sinfonia," in Musik im Exil: Die Schweiz und das Ausland 1918-45, ed. by Chris WALTON and Antonio BALDASSARE (Bern: Peter Lang, 2005), 212-215. Also in 1928, on the occasion of the Schubert centenary, another initiative of a similar nature was announced by the Santa Cecilia Academy in Rome and the American Schubert Memorial Commission, looking for orchestral works in Schubert's style or using Schubert's themes. N. N., "A Schubert-centenárium," Literatura 3/3 (March, 1928), 108.
} 
While the orchestration of the Fantasy in F Minor does reflect the wish for stylistic authenticity, a wish also alluded to in the passage quoted from the memoirs of Elsa Galafrés, it is interesting that Dohnányi's wife does not mention at all - not even as a counterexample - their collective creation. For The Kiss of the Muse was born in a somewhat opposite spirit, given that Dohnányi, too, "intervened" in Schubert's original work. As we will see further below, his modifications include tempo and key changes, cuts, and even minor thematic alterations. Moreover, after the sixth and final movement, Dohnányi inserted a coda recalling the beginning of the first piece in $\mathrm{C}$ major. By doing so, he obviously wanted to strengthen the coherence of the cycle and the stage action. ${ }^{44}$ However, this procedure, commonly used throughout the history of music and especially by nineteenth-century composers, can be considered one of the most emblematic features of Dohnányi's style. ${ }^{45}$ Due to the changes that occurred as a result of the orchestration, and the procedure of recalling thematic material, often used in his own works, we can assume that Dohnányi's version of the Moments musicaux is not a mere orchestration, but also a kind of reconstruction, if not the creation of a new (orchestral) work. It is obvious that the difference between the methods used in the two instrumentations (arrangements) was also due to the fact that while one was intended for a concert hall performance, the other had to adapt to the framework of a stage action, so in the latter case the "intervention" in the original work is not so surprising.

The manuscript score prepared for the stage version of The Kiss of the Muse, preserved at the Music Collection of the Hungarian State Opera House, cannot be studied at present due to the renovation of the Ybl Palace, the Opera's headquarters. A fair copy of the work, made for concert hall performances by a copyist, is preserved in the Dohnányi Collection at the Music Collection of the National Széchényi Library, ${ }^{46}$ but it is not known to what extent it differs from the score kept at the Opera House. The Dohnányi Collection has preserved another source, namely the piano score of the Moments musicaux, ${ }^{47}$ in which Elsa Galafrés introduced the most important moments of the stage action and the gestures of each character. At the same time, this source does not contain any entry from Dohnányi (Plate 1). It is also clear from the same image that Galafrés changed the title of the work - incorrectly - to Moments musicals.

The autograph manuscript of the other orchestration, the Fantasy in F Minor, can be found in the Music Collection of the Philharmonic Society; other sources where Dohnányi recorded the names of instruments to be used - like the piano score used by him, or any other sketches documenting the process of instrumentation - are missing in this case, too.

In the Fantasy, however, Dohnányi did not change the musical material of Schubert's work at all; his additions mainly concern the performance manner (e.g. the remarks "dolce," "espressivo" introduced in the solo instrumental parts), the dynamics ("piano," "pianissimo," "forte," "crescendo," "diminuendo"), and the tempi (with markings such as "Di nuovo più animato," "Scherzando," "Più animato," "energico" added at the beginnings of formal sections). In addition, it can be observed - and this also applies to the orchestration of the Moments musicaux -

\footnotetext{
${ }^{44}$ The return of the first piece, during which the Princess first appears on stage, in the coda of the sixth movement may actually symbolize the disappearance of the Princess at the end of the ballet.

${ }^{45}$ Ilona KOVÁCS, Alkotói folyamat Dohnányi Ernő zeneszerzői mühelyében. A kamarazene-vázlatok vizsgálata [Compositional process in Ernst von Dohnányi's workshop. Studies of sketches for chamber music] (PhD thesis, Budapest: Liszt Ferenc Zenemúvészeti Egyetem, 2009), 84-88.

${ }^{46}$ The shelfmark of the score is Ms. mus. 6062.

${ }^{47}$ The shelfmark of the piano version is Ms. mus. 8101 .
} 


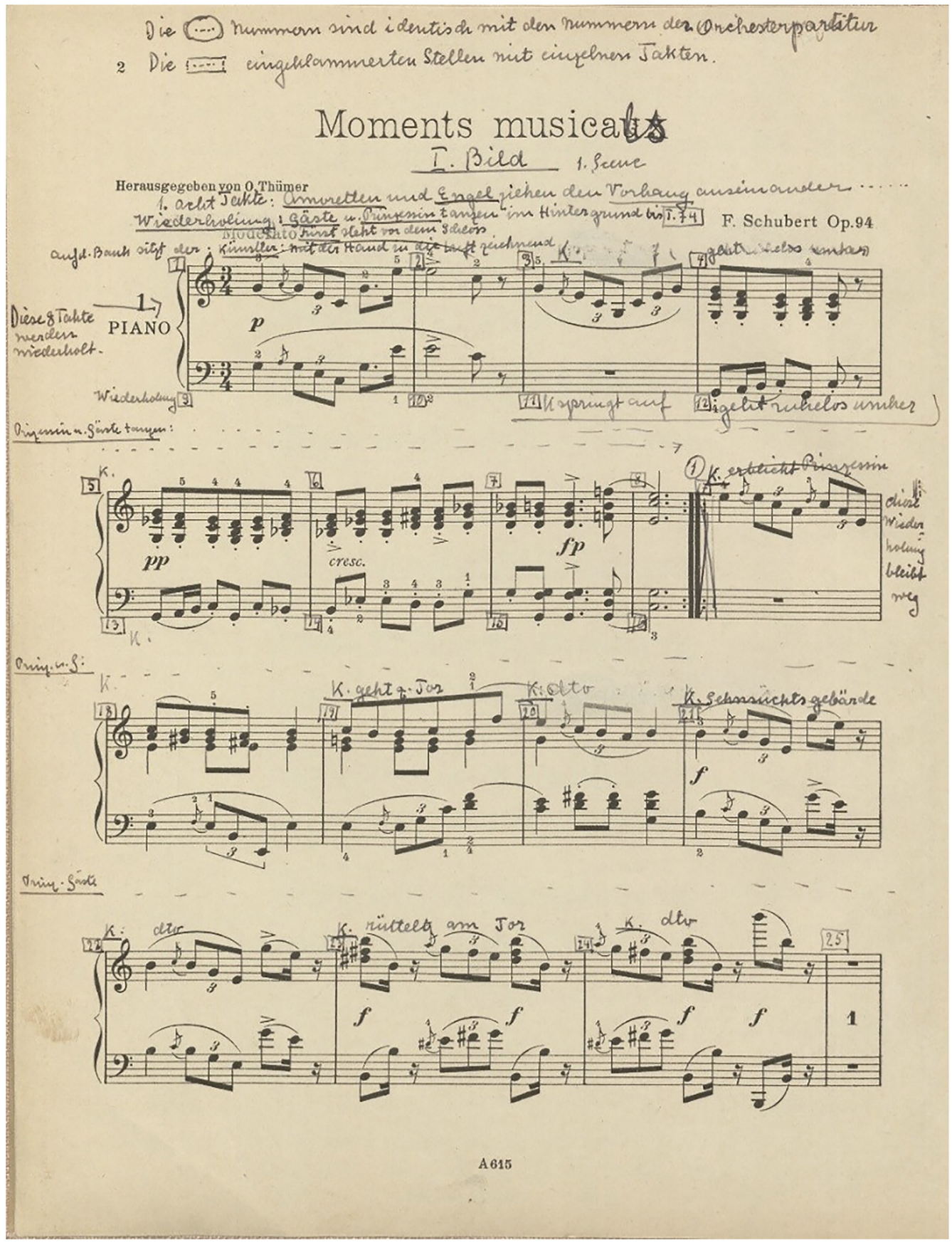

Plate 1. Galafrés Elsa's entries in the piano score of Moments musicaux (Ms. mus. 8101) 
that Dohnányi's orchestral arrangement distributes Schubert's themes in an extremely balanced way between the wind and string parts: the same balanced sound can be heard in the orchestration of Schubert's symphonies. It can also be stated that Dohnányi's instrumentation generally chooses the solo instruments in a way very similar to Schubert's: this aspect mainly concerns the woodwinds. In Dohnányi's orchestration of the Fantasy in F Minor, the starting instrument with a lyrical theme is the oboe, which also plays a prominent role in the last two Schubert symphonies; the opening theme of the second movement of the "Great" Symphony in C Major is played by the oboe; however, the character and atmosphere of this solo theme cannot be compared to the lyrical first theme of the Fantasy in F Minor.

Aladár Tóth, in the continuation of his previously quoted criticism, commented on the distribution of the themes of the Fantasy between string and wind parts as follows:

If, for example, Dohnányi has a theme first played on woodwinds and then on strings, this serves not only the interests of variety, but it also is an explanation of the inner form of the composition. The work will therefore not only be more colorful but also more plastic. Moreover, the poetic sculpture is more important to Dohnányi than the "colorfulness" - in the "Allegro vivace," for example, he constantly prioritizes the flutes from among the woodwinds, meanwhile sparing the oboe, so that the oboe solo of the recurring theme in $\mathrm{F}$ minor can have a deeper impact. ${ }^{48}$

In his description of a fragment, namely the Allegro vivace section, Aladár Tóth makes a valuable statement: according to him, by bringing the flutes to the fore, Dohnányi would have sought to provide the first oboe with a more effective re-appearance in the reprise. As a matter of fact, the lyrical theme of the first movement returns in the finale of the four-movement Fantasy in F Minor, and therefore, the formal structure of the work is interpreted by analysts as a kind of mixture of sonata and cyclic form. ${ }^{49}$

Likewise, in the third movement, the "Scherzo" consisting of three sections, the flute is more prominent than the oboe. This is best felt at the beginning of the "Scherzo's" middle section, the Trio, where the flute part engages in dialogue with the clarinet part (Example 1). ${ }^{50}$ The opening theme of the Trio section is then played by the oboe and clarinet: a similar juxtaposition of both instruments can also be observed in the movements of Schubert's "Unfinished" Symphony. In the "Scherzo" movement, as well as in the fugue to appear later, brass instruments, including trombones and horns, play a prominent role, just as in Schubert's last two symphonies mentioned earlier (Example 2). We may add that Schubert only used trombones in these two symphonies.

It may be seen as an individual solution the way Dohnányi uses the solo violin for the opening theme on its return in F minor, at the end of the first movement marked Allegro molto moderato (Example 3). The triplets preparing the appearance of the theme were condensed by Dohnányi into

\footnotetext{
48“(T-th)” [Aladár TÓTH], “A Schubert-ünnep,” 14.

${ }^{49}$ Analysts also often highlight the structural similarity to the Wanderer Fantasy. Arthur GODEL, "Zum Eigensgesetz der Schubertschen Fantasien," in Schubert-Kongress Wien 1978, ed. by Otto BRUSATTI (Graz: Akademische Druck-und Veranstaltung, 1979), 199; Barbara STRAHAN, (De)Constructing Paradigms of Genre: Aesthetics, Identity and Form in Franz Schubert's Four-Hand Fantasias (PhD thesis, Maynooth, Kildare: Department of Music, National University of Ireland Maynooth, 2013), 240-287. <http://mural.maynoothuniversity.ie/7743/1/BARBARA\%20STRAHAN\%20NUI\% 20MAYNOOTH\%20PHD\%20THESIS\%2020\%20AUG\%202014\%20PDF\%20FOR\%20THESIS\%20CENTRE.pdf> (accessed on January 19, 2021).

${ }^{50}$ The music examples of the Fantasy in F Minor are based on Dohnányi's autograph, kept in the Music Collection of the Budapest Philharmonic Orchestra.
} 


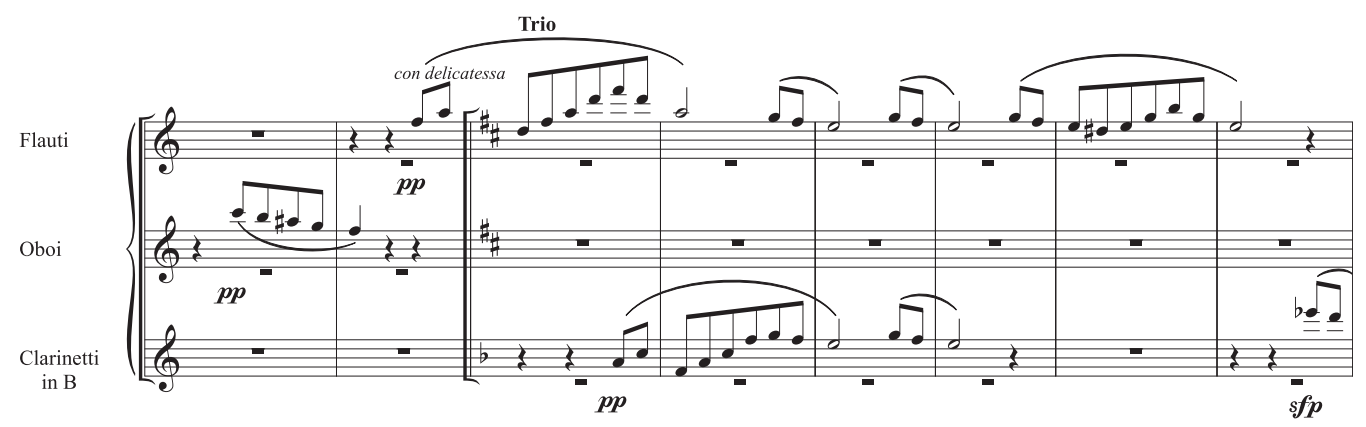

Example 1. Fantasy in F Minor, "Scherzo," mm. 266-273 (beginning of the Trio)

sixteenths (Example 4a-b). The solo violin part was almost certainly played at the premiere by the orchestra's concertmaster, Emil Baré. It is not certain, though not improbable either, that Dohnányi considered the performing style of his musicians during the preparation of his orchestration. Could it be that, during the orchestration of the lyrical opening theme of the Fantasy, Dohnányi was inspired by the memories he preserved of the performance of one of the orchestra's oboists? ${ }^{51}$ Or was he rather influenced by the oboe parts of the last two Schubert symphonies?

In terms of the selection of solo instruments and of the instrumentation in general, the fugal section, marked "Più animato," offered the greatest number of possibilities for Dohnányi, in line with the instruments of the Schubertian orchestral ensemble. He employed an extremely colorful selection of instruments for the individual fugal themes, first using strings, then woodwinds and brass. Following the exposition of the theme at a forte dynamic, Dohnányi chose a translucent chamber music texture for the fugal theme's appearance in A-flat major, now mezzopiano (Example 5). The three-part musical material is performed by only four types of instruments: the theme is played by the horns and bassoons, while the countersubject played by the clarinet and oboe (the latter brings the counter-part in triplets for the first time). After this moment, Dohnányi divides in a similar fashion among the string parts the themes of the double fugue which - before the return of the opening theme - culminates in a grandiose sound produced by the whole orchestra. In this tutti segment, the brass instruments - the trombones, horns and trumpets - play an important role, temporarily conferring a solemn tone on the otherwise rather frantic Più animato section. Although Schubert's symphonies do not include sections of a similar structure, i.e. fugues in strict writing, shorter imitative segments can be found in both the second movement of the "Great" Symphony in C Major and the last movement of the "Unfinished." Imitation or strict counterpoint is more common in Schubert's piano works. These textures can also be observed in the other Schubert composition, arranged for orchestra by Dohnányi: in the fourth movement of the Moments musicaux piano cycle, Moderato, there is a section, suggesting perpetual motion and evoking the Baroque style of Bach's preludes, which is also based on the same principle.

\footnotetext{
${ }^{51}$ The ensemble's oboists at the time were Hugó Heinz, Artúr Kotraschek, Walter Kruyswyk, Antal Juhász, and Peregrin Turry. BÓNIS, A Budapesti Filharmóniai Társaság, 200-201.
} 


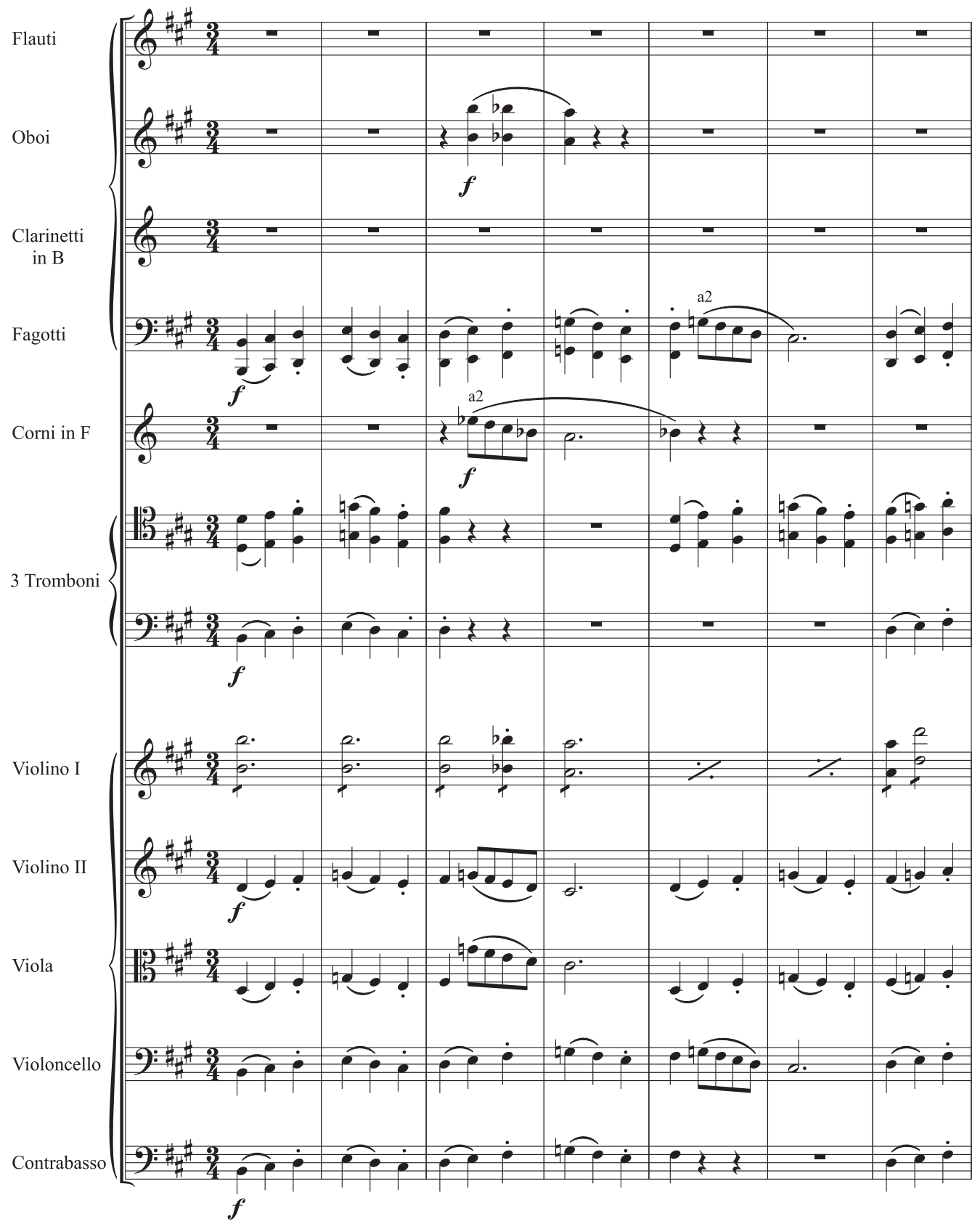

Example 2. Fantasy in F Minor, trombones and horns in the "Scherzo," mm. 211-223 


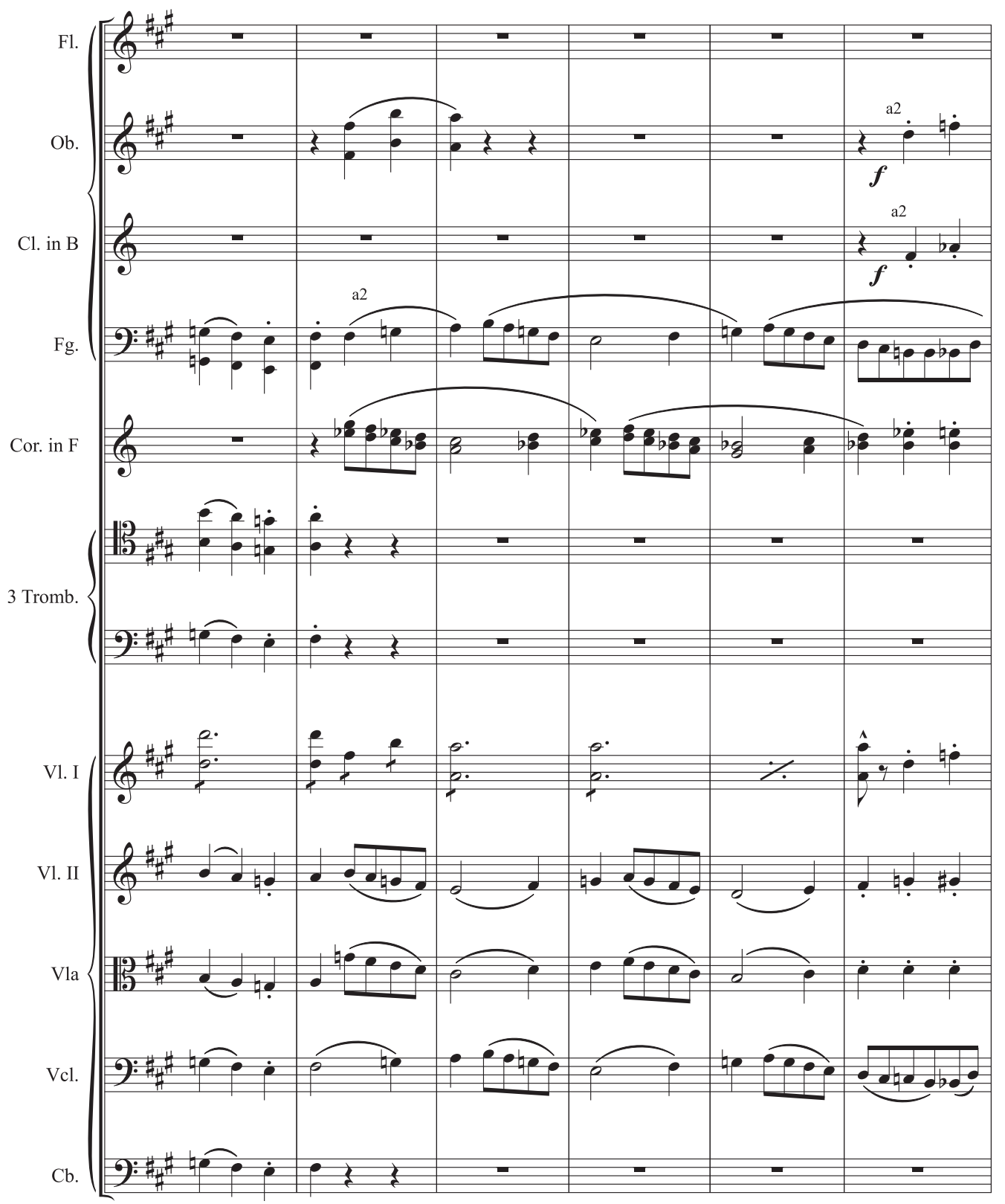

Example 2. continued 


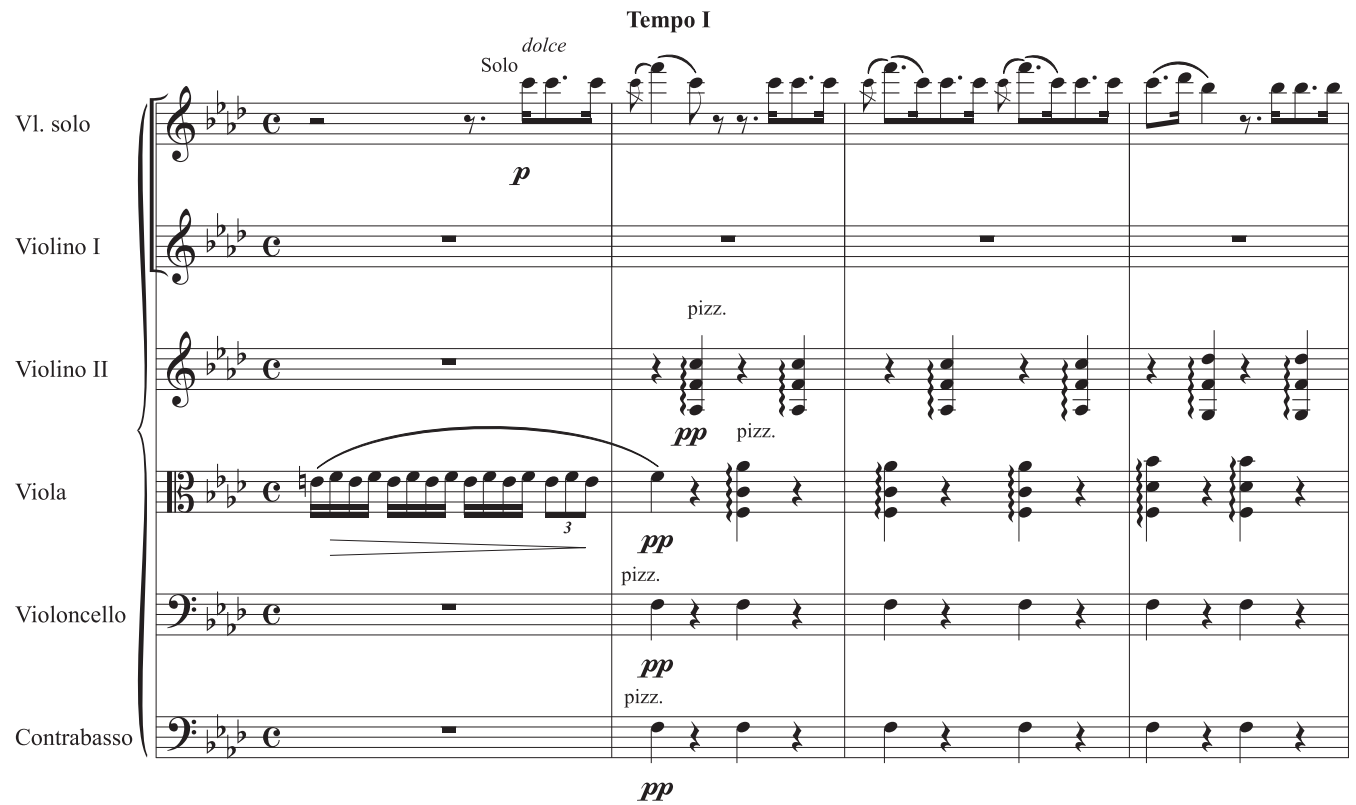

Example 3. Fantasy in F Minor, "mov. I," Allegro molto moderato, mm. 90-93

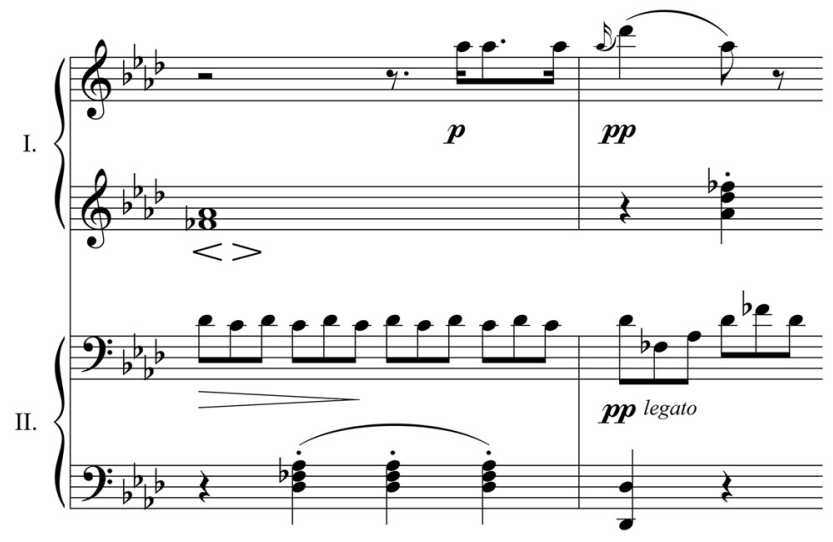

Example 4a. Fantasy in F Minor, mm. 65-66

In The Kiss of the Muse, Dohnányi - perhaps also due to the stage action - allowed himself more freedom while preparing the arrangement. In the middle part of the fifth movement, Allegro vivace (beginning after the repeat mark), he omitted six measures (mm. 25-30) of the 


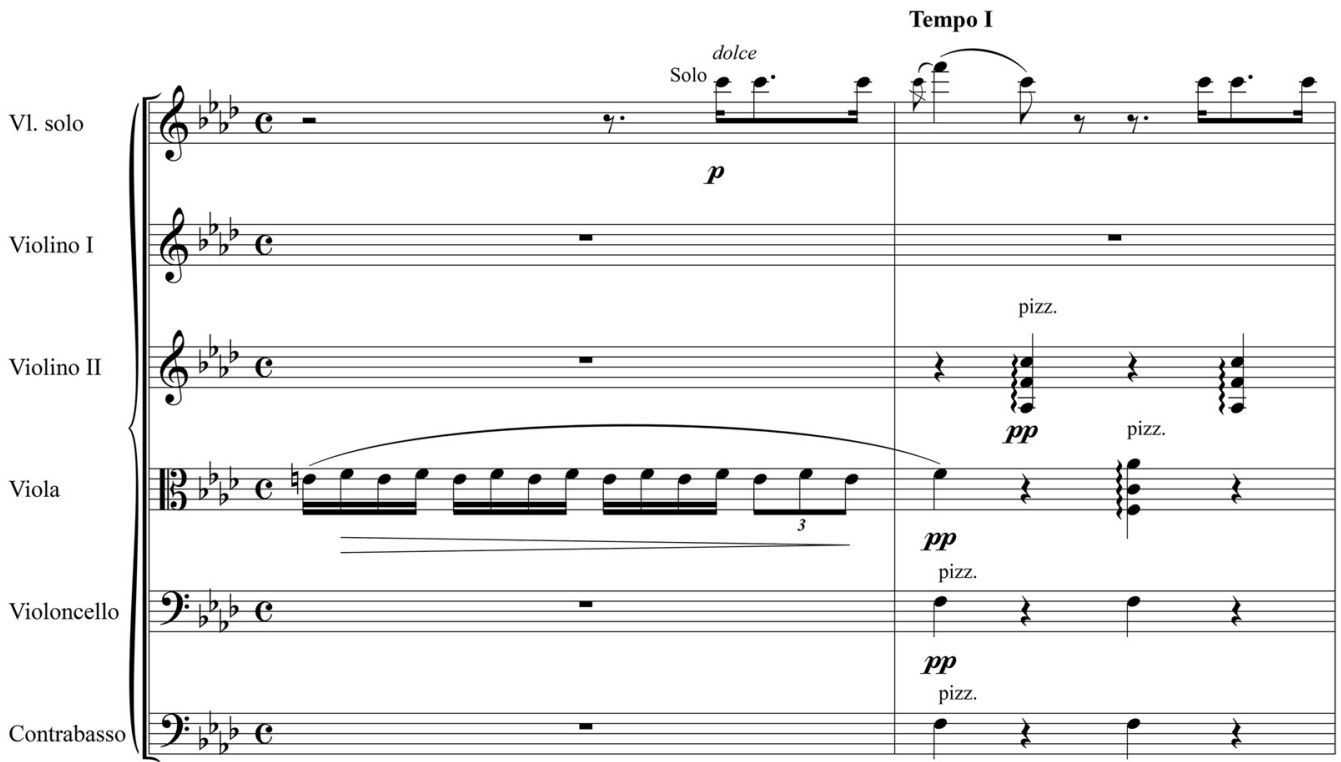

$\boldsymbol{p p}$

Example 4b. Fantasy in $\mathrm{F}$ Minor, mm. 90-91

original musical material (cf. Example $6 a-b){ }^{52}$ It is not entirely clear why he left out the measures in question, but we may find that he was better able to combine the three measures of modulation towards G-flat major, prior to the cut, with the following segment in G-flat major. Apart from this cut, Dohnányi's modifications include the repetition of certain thematic elements. In the main section of the first movement in $\mathrm{C}$ major, Schubert wrote, following a whole measure of rest, a figuration in thirds lasting a total of four measures. Dohnányi's arrangement keeps this movement in thirds for an additional three measures (cf. Example 7a-b). The same procedure is also used at the return of the main section. An example of the reiteration of the opening theme can be found in the fifth movement, Allegro vivace, within the modulation of the middle section: Dohnányi treats this passage of the original Schubert work as an accompaniment by superimposing on it the theme of the movement's main section (Example 6b). With this reiteration he actually breaks down the three-part formal structure of the Schubert composition and creates a new design, based on a kind of variational principle. This procedure might be considered to be fully intended, as in Dohnányi's compositional output variation generally is of central importance, accompanying his entire œuvre. ${ }^{53}$

\footnotetext{
${ }^{52}$ The music examples of Moments musicaux are based on the fair copy Ms. mus. 6062, Dohnányi Collection, Music Collection of the National Széchényi Library.

${ }^{53}$ Veronika KUSZ, “Dohnányi variációs stílusa Szimfonikus percek (op. 36) címü zenekari müvének IV. tételében, »Tema con variazioni«" [Dohnányi's variation style in the fourth movement of his orchestral work Symphonic Minutes (op. 36): »Tema con variazioni«], in Dohnányi Évkönyv 2003, ed. by Márta SZ. FARKAS and Deborah KISZELY PAPP (Budapest: MTA Zenetudományi Intézet, 2004), 99-100.
} 

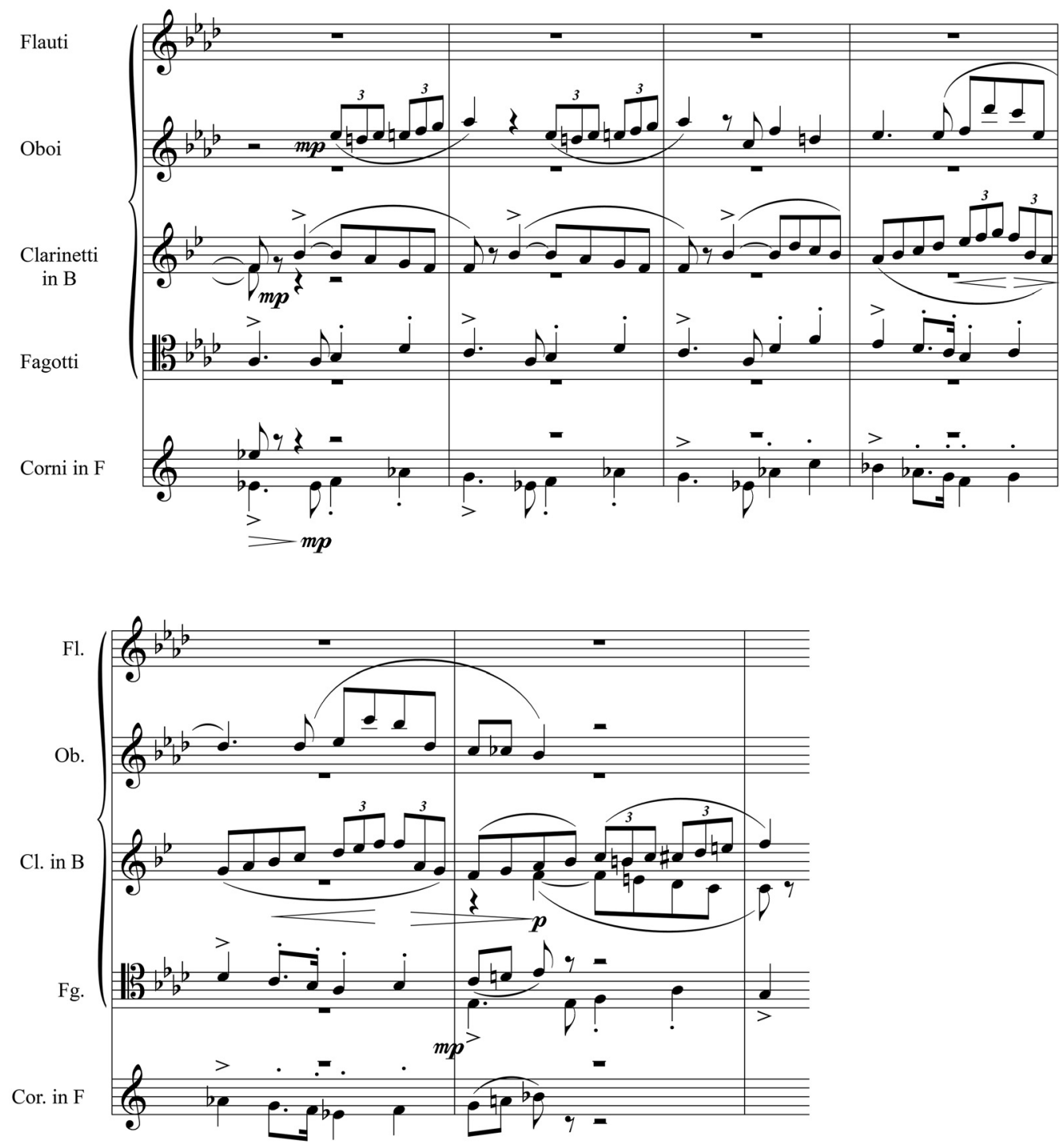

Example 5. Fantasy in F Minor, "Finale," Più animato, mm. 351-357

The explanation for Dohnányi's modifications and additions may also be found in the fact that, compared to the polyphony of the Fantasy in F Minor, the pieces of the Moments musicaux series have a simpler writing, so by re-using thematic elements, Dohnányi could have sought to enrich the sound of his orchestration. At the same time, as we have already seen above, Dohnányi tried to create a balance between wind and string parts, and allowed the solo instruments - especially the woodwinds - to appear here, too, in a way that is similar to the last two Schubert symphonies. 

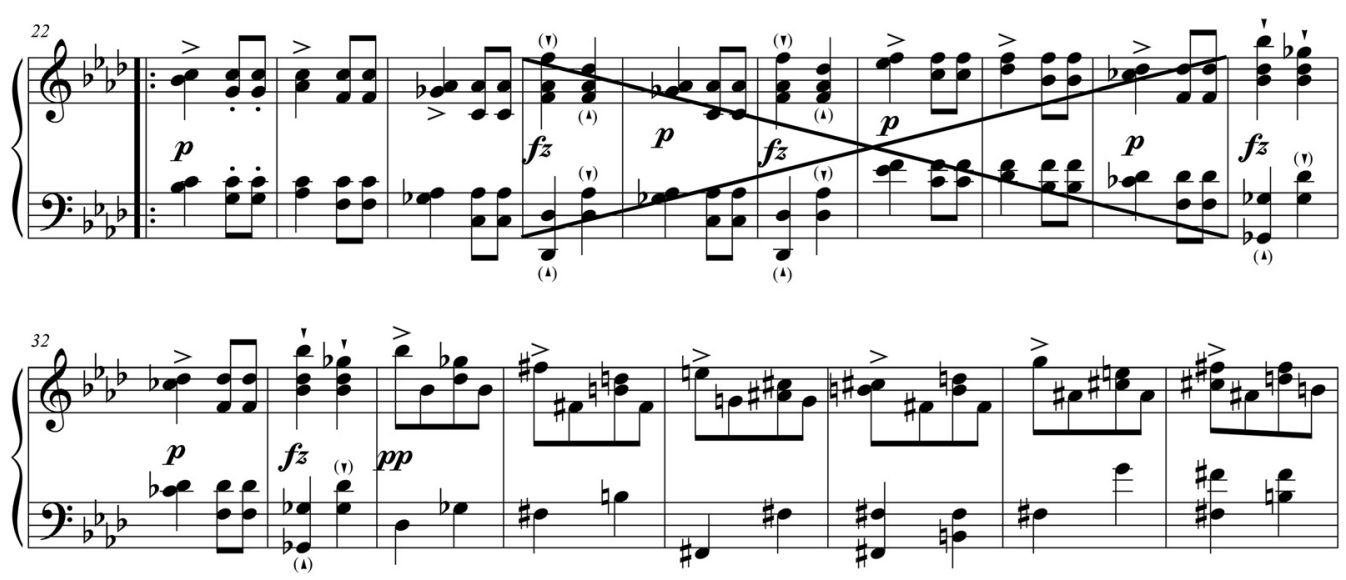

Example 6a. Schubert, Moments musicaux, no. 5, mm. 22-38 with mm. 25-30 omitted

In the individual movements of the Moments musicaux orchestration, we find some of the solutions Dohnányi had already applied in the case of the Fantasy in F Minor. In movement 6, Allegretto espressivo, Dohnányi uses the solo violin again. The brass instruments, especially the horns, also play a prominent role several times in the piece. The horns also appear in the first movement, evoking a bucolic athmosphere in $\mathrm{C}$ major - this is quite an obvious solution, as the horn signals with their characteristic dotted rhythm motifs were already present in the original piano version (Example 8). The horns also play with mutes (con sordino) in movement 6. Examples of the distribution of themes in dialogue between wind and string blocks - as we have seen before in the Fantasy in F Minor- can be also found in movements 2 and 6 of the Moments musicaux. In the latter piece, Dohnányi divided the entire string section, most likely in order to emphasize the inner content of the lyrical theme (Example 9a). A further example of the division occurs in the imitative fourth movement, where Dohnányi split the wind instruments and the first and second violins into several parts in order to emphasize the polyphonic structure (Example 9b). Interestingly enough, Dohnányi changed both the tempo and key of this movement, compared to the original work by Schubert. While the only fast-paced movement in the Schubert cycle was the fifth, Allegro vivace, Dohnányi's arrangement changed the tempo of movement 4 from Moderato to Allegro non troppo. Thus, in the middle section of his arrangement - i.e. the successive movements 4 and 5 - Dohnányi created a fast-paced segment. We may add that the content of the stage action probably played a role in the tempo modification for movement 4, as this scene depicts the struggle of allegorical figures, i.e. Cupid's army, angels, and devil chicks hindering the love of the Poet and Princess (for the ballet's scenario, see the Appendix of this article).

The tempo of movement 6, Allegretto, was somewhat modified by Dohnányi, insofar as he added the term espressivo. By doing so, he probably wished to better convey the atmosphere of the lyrical movement, but he could also have referred to the content implied by the title of the movement in the earlier publication of 1824: Plaintes d'un Troubadour (Complaints of a troubadour). The stage action of the sixth scene rhymes with Schubert's title, as at this point in 


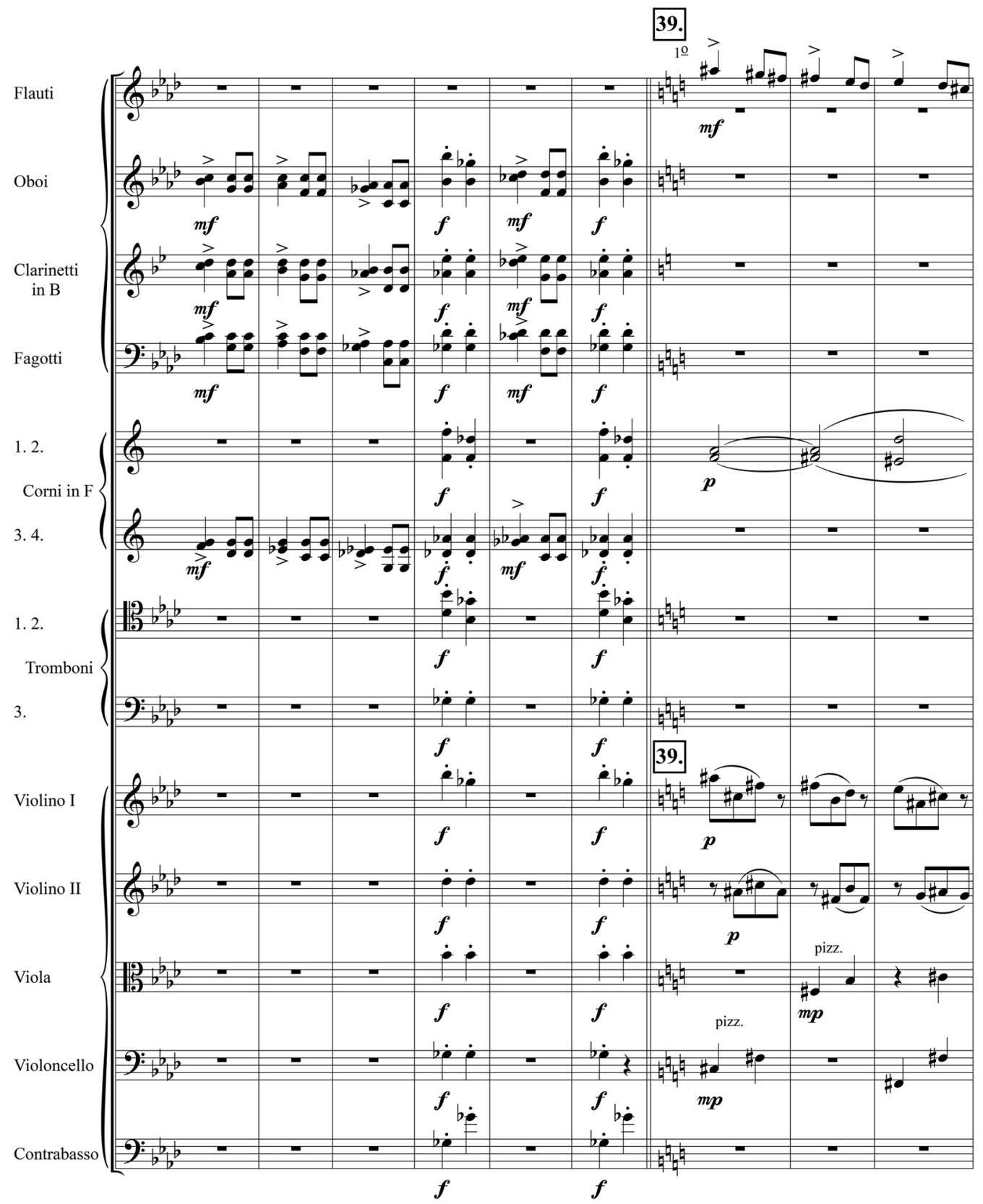

Example 6b. Dohnányi, Moments musicaux, no. 5, mm. 22-30 

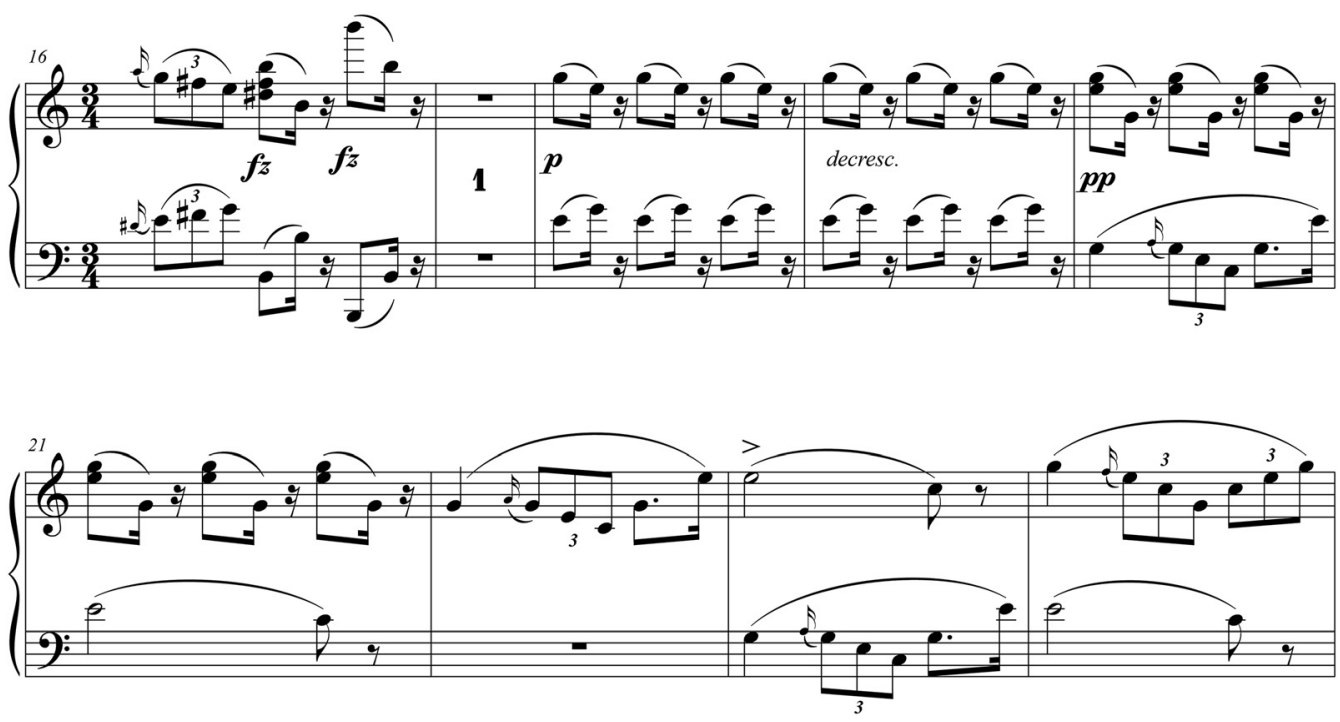

Example 7a. Schubert, Moments musicaux, no. 1, mm. 16-24

the libretto of Elsa Galafrés, instead of Schubert's troubadour, the music depicts the Poet's loneliness and internal agony.

In addition to the tempo changes, Dohnányi adjusted the basic key of a single movement. Schubert's fourth movement in C-sharp minor was arranged by Dohnányi in C minor. This can easily be explained by the fact that for the tonal strategy of concatenated movements - C major, A-flat major, $\mathrm{F}$ minor, $\mathrm{C}$ minor (instead of C-sharp minor), F minor, A-flat major, (C major) - the $\mathrm{C}$ minor was more appropriate, and with the movement recalled at the end of the work in $\mathrm{C}$ major, Dohnányi created a palindrome or arch-like tonal structure. ${ }^{54}$ At the same time, with this change, Dohnányi produced a closed form for his orchestration of the cycle, a closed form similar to that of the Fantasy in F Minor, which stands out as a separate work.

Clearly, these Schubert arrangements for orchestra do not fully reflect the brilliant and colorful orchestral technique typical of Dohnányi's own compositions. However, it is also clear that we can discover only partial similarities between Schubert's symphonies and Dohnányi's solutions for his instrumentation, since Schubert envisioned the individual themes for specific instruments, while Dohnányi orchestrated Schubert's themes based on already existing musical material. Yet, these orchestrations reveal not only Dohnányi's unique abilities in instrumentation, but also his particular interpretation and image of Schubert.

\footnotetext{
${ }^{54}$ This key change could have been motivated by the winds' easier intonation in C minor as compared to the tonality of C-sharp minor.
} 

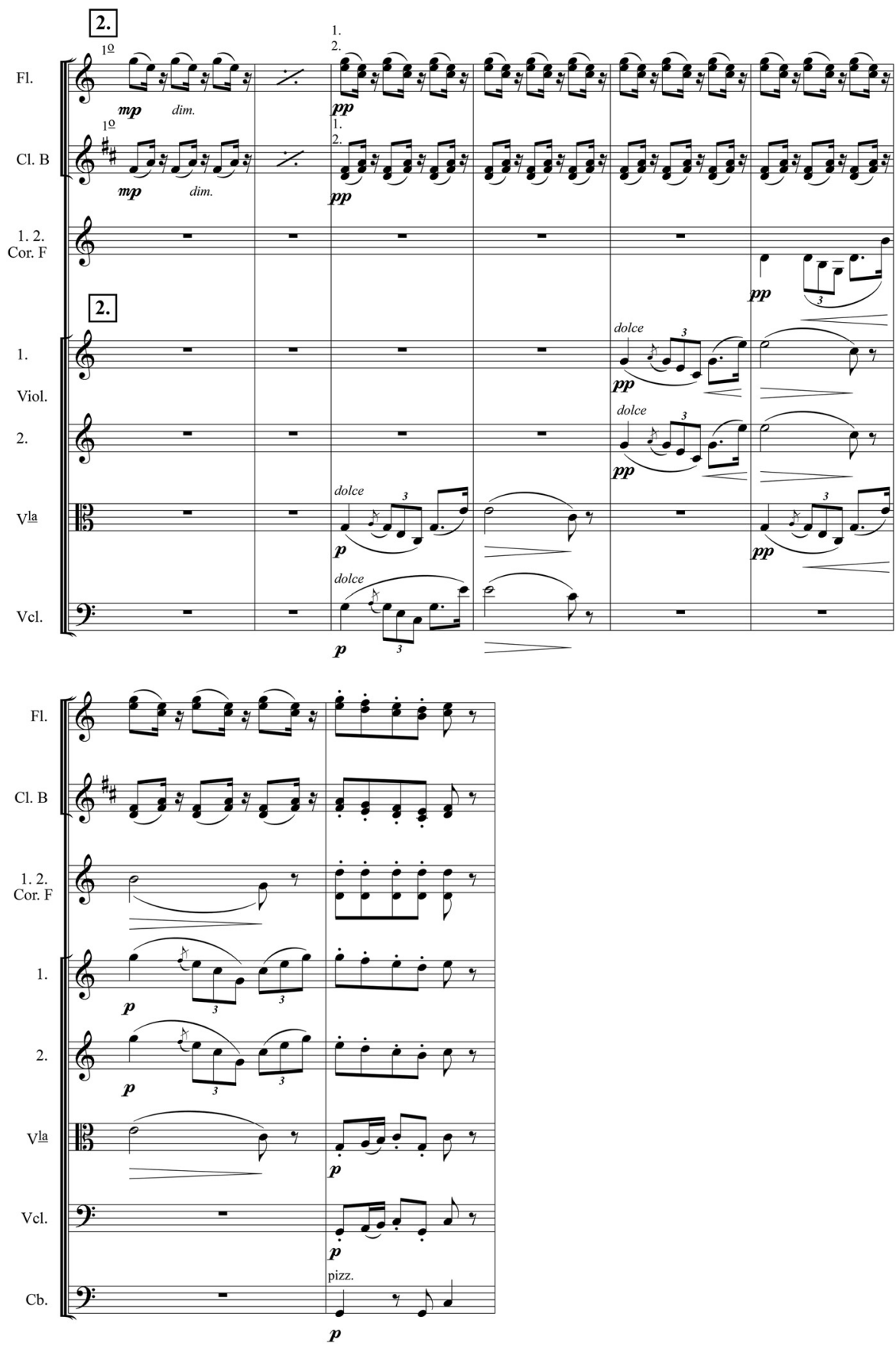

Example 7b. Dohnányi, Moments musicaux, no. 1, mm. 18-25 


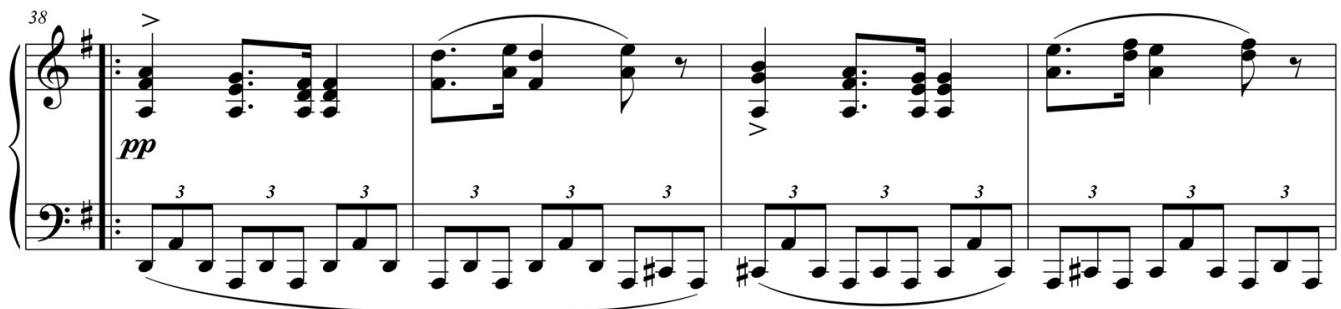

Example 8. Schubert, Moments musicaux, no. 1, mm. 38-41

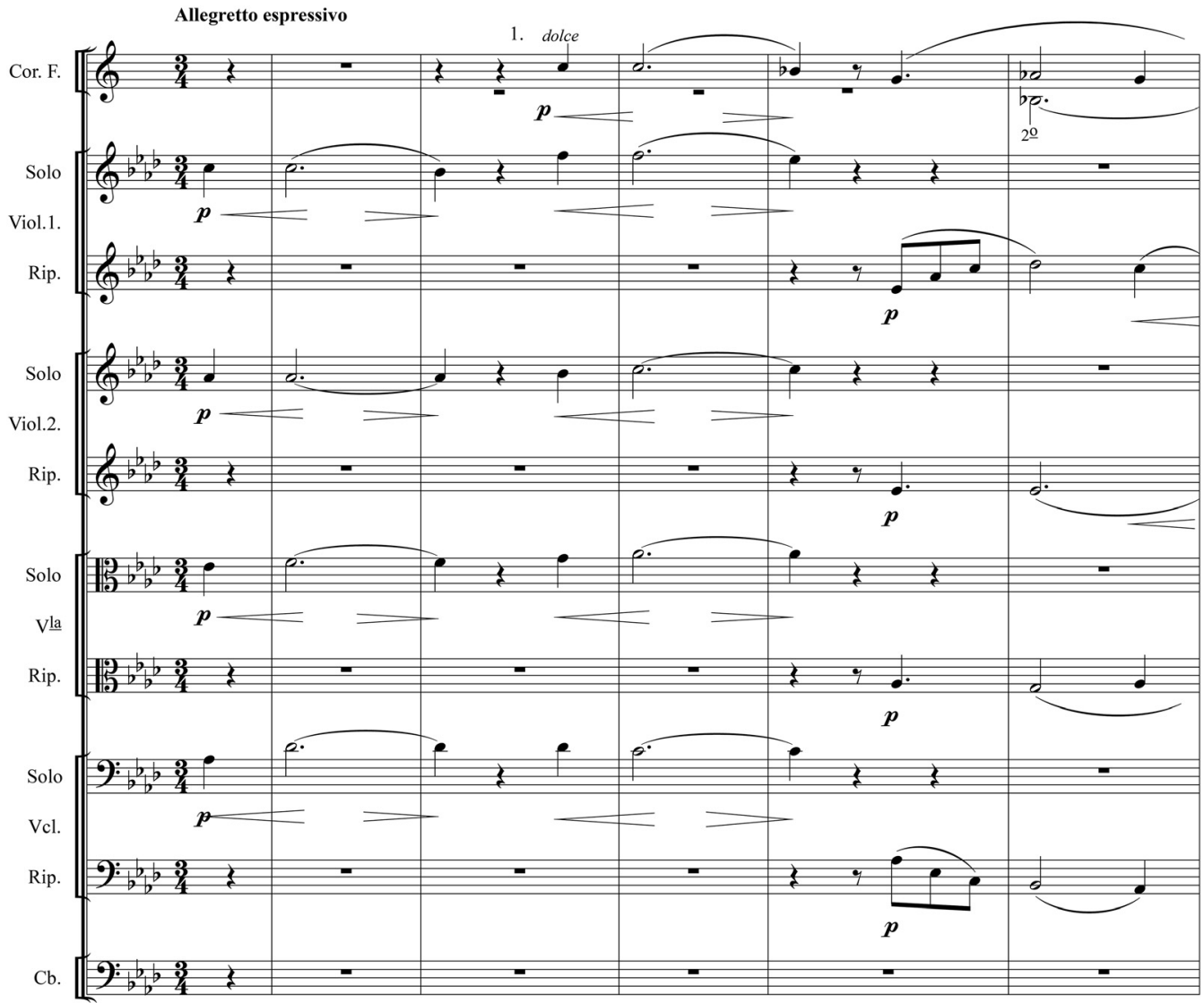

Example 9a. Dohnányi, Moments musicaux, no. 6, mm. 1-5 


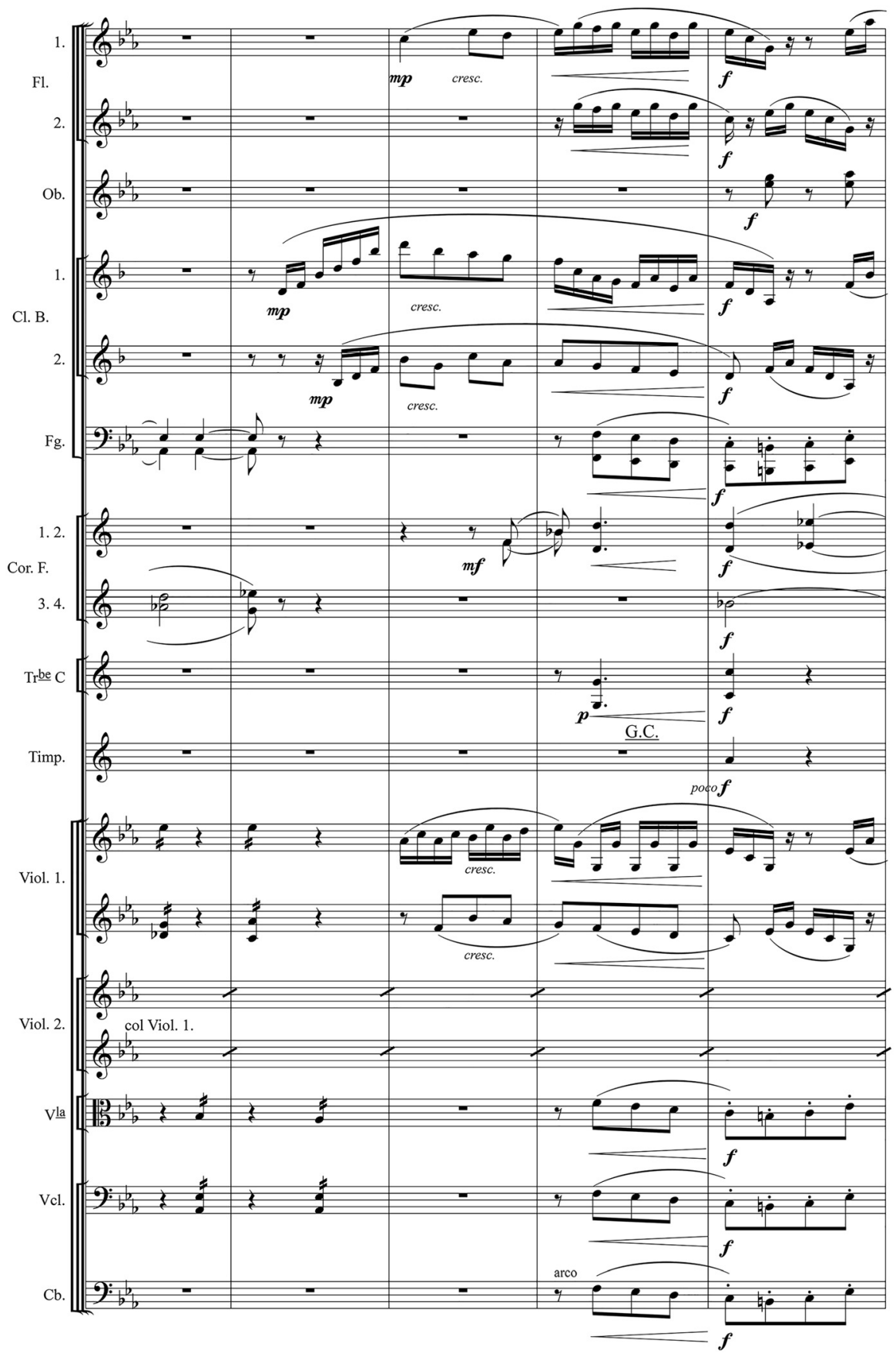

Example 9b. Dohnányi, Moments musicaux, no. 4, mm. 27-31 


\section{APPENDIX}

\section{Elsa Galafrés, The Kiss of the Muse}

Prologue [The argument of the stage action, written by László Márkus].

\section{Scene 1}

In the garden of pure beauty, the Prince and the Princess welcome their guests. Immersed in his thoughts, the Poet agonizes outside the garden. Behind the solid wall that separates two worlds, he sees the Princess and, longing for her perfect beauty, he extends his arms toward her. He is spotted by the Princess of Dreams and a curious glimpse of hers shines on the Poet. Little Cupid captures this look, slips under the golden gate, and, with a mischievous smile, sneaks after the Princess into the castle.

\section{Scene 2}

The Poet is sitting thoughtfully. He doesn't want to give, no, he would like to get something. The Angel, willing to alleviate all suffering, approaches him and leads him to the Muse: Here is the blessed hand that always gives abundantly! The Poet touches the cold stone. He shakes his head with a painful smile. Longingly, he extends his arms towards the castle. The Angel awakens the sacred fire of the Muse. The Muse wakes up and touches the strings of the lute. The high reliefs on the stone wall - all symbols of the Poet's thoughts - awaken to life and, for a moment, force the Poet into their circle. But Cupid appears on the stairs and, on the silk ribbon of love, leads the Princess down to the castle gate. The Muse solidifies into cold stone again, and the Poet's thoughts freeze into the high reliefs of the garden wall. The little Princess is still scared. Alarmed, she glances back at the castle. But the Poet's desire calls upon her more and more vehemently. The two are only separated now by the golden gate. The Princess teasingly throws the silk ribbon, which the Poet catches and presses passionately against his lips. Once again, the song of the Muse is heard. The Poet notices it, but behold, a miracle is happening now: at Cupid's signal, the golden gate, closed with seven locks, opens. It is a new, scary, unknown world here, that the Poet is showing outside of the gate. The Princess looks around. She trembles and shyly deflects the embrace of the Poet, who, with deep attachment, falls to his knees before her. It is a sacred minute of pure love.

\section{Scene 3}

The sweet Sin, the light-footed dancer, walks dancingly on life's broad path; she is followed by the Rake, he himself in the pursuit of sensual pleasures and joys. The dancing Sin awakens a desire in the Poet for the ardent kiss of life. With dizziness, he approaches her inhaling the sweet venom of Sin, and would go with her to the pavilion. But the Rake precedes him, sneaking into the pavilion in the footsteps of the dancing Sin. With a mocking smile, she slams the door in front of the dreamy, longing Poet.

\section{Scene 4}

The Poet wakes up. He looks at the Princess, who, like a frightened little bird, leans against the wall. This is life? This is love? She would run back behind the protective walls, to her home, but the golden 
gate remains relentlessly closed. Cupid calls his small army for help, to lead the Princess back to the Poet. But the Angel also calls on his little companions and fights with them against Cupid's army, which they manage to remove from the gate. The Angel opens the golden gate and gives the disillusioned child a free path to the castle. In vain does the Poet prove his love, the Princess's small hand points in disappointment toward the homestead of sins, the pavilion. She continues up the steps of the stairs. The golden gate closes and the Princess disappears from the Poet's eyes. But the accomplices of the deceitful Rake do not rest either. Devil chicks cheat, inviting the Poet to the farm of savage lust. They fight the angels willing to save him. The devil chicks call back the angels from the pavilion door. Only now the Poet turns away, with disgust, from the house of sinful pleasures.

\section{Scene 5}

The Sin and the Rake, with a crowd of dancing couples, leave the pavilion in a lush, wild dance. The flame of savage pleasures envelops the Poet once more, but, purified of sensual desires, he scatters the seducers in disgust.

\section{Scene 6}

Loneliness and deep silence surround the Poet. He stands there broken, mourning the lost ideal, disgusted by the rough, sensual desires, disappointed and helpless in the hustle and bustle of life. Then the little benefactor, the Angel, gently leads him to his Muse. The shocked Poet falls on his knees in front of her. The Muse revives in him the sacred flame of creation. The high relief awakens, thoughts emerge from the frozen stone, floating around it. The minutes of experience are shaped into eternal artwork. Like silhouettes, princely guests glide from the castle into the darkness of the park. Behind the illuminated windows, the Princess re-appears one last time. She is moving further and further away. Everything is obscured. Blurring shadows... brief, fleeting moments.

Translated by István Csaba NÉMETH

\section{ACKNOWLEDGMENT}

The present study was supported by a project of the Hungarian National Research, Development and Innovation Office (K 123 819).

Open Access. This is an open-access article distributed under the terms of the Creative Commons Attribution 4.0 International License (https://creativecommons.org/licenses/by/4.0/), which permits unrestricted use, distribution, and reproduction in any medium, provided the original author and source are credited, a link to the CC License is provided, and changes - if any - are indicated. (SID_1) 